\title{
Histomorphometric analysis of intrapulmonary vessels in patients undergoing bidirectional Glenn shunt and total cavopulmonary connection
}

\author{
Ujjwal K. Chowdhury, MCh, Diplomate NB, Raghu M. Govindappa, MS, Prasenjit Das, MD (Pathol), \\ Ruma Ray, MD (Pathol), FRC (Path), Mani Kalaivani, MSc (Biostatistics), and Srikrishna M. Reddy, MCh
}

Objectives: The purposes of this study were to elucidate the histomorphometry of the intrapulmonary arteries in patients undergoing univentricular type of repairs and to identify the histomorphometric characteristics, if any, that may predispose patients to postoperative Fontan failure.

Patients and methods: Operatively resected wedges of lung tissue from 44 patients undergoing univentricular type of repairs (aged 17 months to 34 years; mean, $83.52 \pm 75.90$ months) was subjected to histomorphometric analysis.

Results: Despite pulmonary arterioplasty, a low Nakata index was associated with 9.61 (95\% confidence interval: $1.01-91.5 ; P=.003)$ times increased risk of death after the operation. A statistically significant difference in the mean indexed diameter of the intra-acinar pulmonary arteries $(P=.03)$ was observed between patients undergoing superior and total cavopulmonary connections. Overall, there were $8(8.2 \%), 4(9.1 \%), 13(29.5 \%)$, and $29(65.9 \%)$ instances of intrapulmonary arterial intimal lesions, thrombosis, smooth muscle extension, and interstitial fibrosis, respectively. Among patients undergoing total cavopulmonary connection, only low Nakata index was significantly associated with the presence of severe intimal lesions, abnormal smooth muscle extension, intra-acinar pulmonary arterial thrombus, and smaller intra-acinar pulmonary arteries.

Conclusions: A low Nakata index is significantly associated with the presence of severe intimal lesions, thrombus, abnormal smooth muscle extension, a lower mean indexed area of the intrapulmonary arteries, and poor postoperative outcome. However, none of the histomorphometrically derived parameters could conclusively predict the outcome after univentricular repair. (J Thorac Cardiovasc Surg 2010;140:1251-6)

Supplemental material is available online.

Despite fulfilling the indications based on hemodynamic data, systemic ventricular mass, pulmonary artery (PA) size with an unobstructed, unrestricted Fontan pathway, and a fenestrated atrial baffle, a subset of patients in the postoperative period has low cardiac output and marked accumulation of extracellular fluid resistant to medical treatment and dies owing to elevation of pulmonary vascular resistance (PVR) and ventricular failure. ${ }^{\text {E1-E7 }}$

It is widely known to clinicians that in patients undergoing the univentricular type of repairs with borderline Nakata

\footnotetext{
From the Cardiothoracic Sciences Centre, AIIMS, New Delhi, India.

Disclosures: None.

Received for publication Nov 3, 2009; revisions received April 29, 2010; accepted for publication May 16, 2010; available ahead of print July 12, 2010.

Address for reprints: Ujjwal K. Chowdhury, MCh, Diplomate NB, Additional Professor, Department of Cardiothoracic and Vascular Surgery, All India Institute of Medical Sciences, New Delhi-110029, India (E-mail: ujjwalchow@rediffmail.com; ujjwalchowdhury@gmail.com). 0022-5223/\$36.00

Copyright (c) 2010 Published by Elsevier Inc. on behalf of The American Association for Thoracic Surgery

doi:10.1016/j.jtcvs.2010.05.015
}

index, the intrapericardial PAs can always be surgically augmented to the desired width and PVR is determined in the peripheral vascular bed, well beyond the surgeon's reach. ${ }^{\text {E8 }}$ Autopsy studies have suggested that in patients undergoing univentricular repair, intra-PA structure cannot always be inferred from the preoperative hemodynamic data. Medial hypertrophy and/or decreased intra-PA concentration have been reported to exist in these patients with normal PA pressure and PVR. ${ }^{\text {E9-E14 }}$

On the basis of these observations, we hypothesized that in the presence of an unrestricted Fontan pathway, these microvascular changes could be the contributing factor for high PVR in the postoperative period. However, histopathologic or ultrastructural studies of the lung tissue to lend credence to this hypothesis have been limited and controversial because of limited number of patients and restricted observations. ${ }^{\text {E1-3,E9-E11 }}$ Second, patients who had died because of definite technical problems were not excluded from analysis of outcome. $^{\text {E1-E4,E12-E15 }}$

With this background, we conducted this study (1) to elucidate the histopathology and morphometry of the intrapulmonary vessels of patients undergoing the univentricular-type of repair (ie, superior cavopulmonary connection [SCPC]) and total cavopulmonary connection [TCPC]); (2) to identify the relationship, if any, between the histomorphometry and 


\section{Abbreviations and Acronyms \\ $\mathrm{CI}=$ confidence interval \\ PA = pulmonary artery (arterial) \\ PAP = pulmonary artery pressure \\ PVR = pulmonary vascular disease \\ $\mathrm{SaO}_{2}=$ systemic arterial oxygen saturation \\ SCPC = superior cavopulmonary connection \\ SVEDP $=$ systemic ventricular end-diastolic pressure \\ TCPC $=$ total cavopulmonary connection}

preoperative hemodynamic parameters; (3) to identify the relationship of intra-PA structure to postoperative outcome; and (4) finally, to determine whether histologic criteria of the intrapulmonary vasculature could be established in decision-making for appropriate selection of patients for univentricular repairs.

\section{PATIENTS AND METHODS \\ Criteria for Patient Selection}

Selection criteria for 1-stage univentricular repair. In this study, patients with a functionally univentricular heart and satisfying the following standard prescribed criteria underwent 1-stage univentricular repair:

1. Satisfactory PA size (preoperatively and intraoperatively measured $\mathrm{PA}$ size with a Z-value $>-2$, McGoon ratio $>2.0$, and/or Nakata index $>250 \mathrm{~mm} \cdot \mathrm{m}^{-2}$ )

2. Mean PA pressure less than $15 \mathrm{~mm} \mathrm{Hg}$ or more than $20 \mathrm{~mm} \mathrm{Hg}$ with a net left-to-right shunt

3. An indexed PVR less than $3.0 \mathrm{Wood}$ units $/ \mathrm{m}^{2}$ and a preoperative Mayo index less than 4.0

4. Satisfactory systemic ventricular function (end-diastolic pressure $[($ SVEDP $] \leq 12 \mathrm{~mm} \mathrm{Hg}$, systemic ventricular ejection fraction $\geq 0.35)$

5. No significant systemic ventricular hypertrophy (assessed by systemic ventricular mass and/or systemic ventricular posterior wall thickness) with a Z-value of less than -4.0

6. No left ventricular outflow obstruction (echocardiographically, a cross-sectional area of the bulboventricular foramen or ventricular septal defect $>2.0 \mathrm{~cm}^{2} \cdot \mathrm{m}^{-2}$ )

7. No more than mild aortic or left atrioventricular valve regurgitation

Subsequently, these patients were grouped according to Texas Heart Institute Fontan Risk score. ${ }^{\text {E16 }}$ Patients with a score of 0 to 3 were considered to be at low risk for a Fontan operation, those with a score of 4 to 5 were considered to be at moderate risk, and those with a score of 6 or more or with a score of 3 in any single category of Texas Risk score were subjected to SCPC as an interim palliation.

Selection criteria for extracardiac Fontan procedure. On the basis of our early experience, extracardiac TCPC was performed in patients with (1) age older than 3 years, (2) body weight of $10 \mathrm{~kg}$ or more, (3) anomalies of systemic and pulmonary venous return, (4) auricular juxtaposition, (5) completion Fontan after a previous SCPC connection, and (6) no requirement for additional intracardiac procedures. ${ }^{\mathrm{E}}$

\section{Conduct of the Study}

Patients were enrolled for this prospective study after institutional ethics committee approval and informed written consent from parents/guardians.
Between January 2006 and July 2009, specimens of excised lung tissue from 50 consecutive patients undergoing either SCPC or TCPC at our institute were subjected to histopathologic and morphometric analysis. Of these, 44 samples from 44 patients ( 32 male subjects) were found suitable for analysis (6 were excluded because of morphologic artifacts resulting from inadequate fixation and/or poor orientation). The examiners were blind to demographic and clinical data including hemodynamic and operative data.

Age at operation was 17 months to 34 years (mean $83.52 \pm 75.90$ months) with $77.3 \%(n=34)$ of patients being younger than 48 months of age. Cardiac catheterization and angiocardiography were performed on all patients to confirm the diagnosis, to define PA anatomy, to measure PA pressure (PAP), and to identify major aortopulmonary collateral arteries (E-Appendix 1).

Twenty-nine $(65.9 \%)$ patients had tricuspid atresia, and the remaining $15(34.1 \%)$ patients had complex cyanotic congenital heart diseases with a functionally univentricular heart. Eight $(18.2 \%)$ patients had right atrial isomerism. Twenty-one ( $47.8 \%$ ) patients had various palliative procedures before univentricular repair. Four patients had bilateral superior venae cavae. Patients with moderate or severe atrioventricular valve regurgitation $(\mathrm{n}=2)$ underwent lateral tunnel TCPC with concomitant atrioventricular valve repair. Descriptive characteristics, underlying cardiac diagnoses, and the relevant cardiac catheterization data are summarized in Table E1.

Hemoglobin value ranged from 11 to $24 \mathrm{~g} / \mathrm{dL}$ and systemic arterial oxygen saturation $\left(\mathrm{SaO}_{2}\right)$ was $65 \%$ to $91 \%$. Mean PAP or pulmonary capillary wedge pressure ranged between 12 and $18 \mathrm{~mm} \mathrm{Hg}$ (mean $\pm \mathrm{SD}=14.25 \pm$ $1.78 \mathrm{~mm} \mathrm{Hg}$ ) and mean SVEDP ranged between 10 and $16 \mathrm{~mm} \mathrm{Hg}$.

In 3 patients with severe pulmonary stenosis and deep cyanosis, pulmonary venous wedge pressure was used as a substitute for PAP for calculation of PVR at preoperative cardiac catheterization. PA size measured intraoperatively with a Hegar dilator was compared with the anticipated confidence limits for age and body surface area, and a 1-stage univentricular repair was carried out as per the selection criteria. A localized PA narrowing reducing adjacent PA diameter by $50 \%$ or more before its branching was an indication for pulmonary arterioplasty.

All patients were operated on with cardiopulmonary bypass using aortabicaval cannulation and moderate systemic hypothermia. The ligamentum arteriosum or persistent ductus arteriosus was divided in all cases, the Blalock-Taussig shunt was divided $(n=17)$, and unilateral $(n=40)$ or bilateral $(\mathrm{n}=4)$ SCPC was performed. The SCPC was carried out on a beating perfused heart. Antegrade cold blood cardioplegia was used for myocardial protection and was repeated every 30 minutes to complete the Fontan connection in 13 patients.

Total extracardiac right heart bypass was accomplished with a polytetrafluoroethylene conduit on a beating, perfused heart without cardioplegia. Size of the conduit and weight distribution of the patients were as follows: polytetrafluoroethylene conduit $18 \mathrm{~mm}$ : 1 patient, $16 \mathrm{~kg}$; $20 \mathrm{~mm}$ : 1 patient, $24 \mathrm{~kg}$.

After completion of the surgical procedure and disconnection of the patient from cardiopulmonary bypass, lung biopsy tissue from the lower lobe of the right lung $(n=39)$ was obtained through a small pleural opening. In patients with a previous Glenn shunt, a biopsy specimen was taken from the lower lobe of the left lung $(n=5)$. A Cooley vascular clamp was applied and a small portion of the lung tissue $(1.0 \times 0.5 \mathrm{~cm})$ was excised for histopathologic examination. The raw margin was sutured in 2 layers. The pleural cavity was closed in all cases. No complications related to lung biopsy, such as pneumothorax or bleeding, were observed in any of the cases.

\section{Analysis of Lung Tissue}

Each lung biopsy specimen was analyzed by 2 pathologists independently without any knowledge of demographic, hemodynamic, and operative data. At least 20 intra-acinar small PAs having a diameter greater than $100 \mu \mathrm{m}$ were examined for histomorphometric studies. There was no interobserver disagreement on the interpretation of the presence or absence of disease. 
Imaging. Representative photomicrographs of at least $20 \mathrm{PAs} /$ pulmonary arterioles were taken by using $20 \times$ objective on an Olympus BX50 microscope (Olympus Corporation, Tokyo, Japan). Appropriate digital images satisfactory for image morphometry were created.

Image morphometry. Only the arteries/arterioles accompanying the secondary or tertiary airways rather than bronchial arteries were selected for study (Figure E1, $A$ to $C$ ). Circumferential area, total diameter, medial thickness, and intimal thickness were measured by a specially designed software program in all 20 selected arterioles (Figure E1, $A$ to $C$ ).

Grading of morphometric parameters. Inasmuch as HeathEdwards grading is inappropriate for minor arterial changes, the following morphometric grades were formulated and followed in this study ${ }^{\mathrm{E} 17}$ :

Normal: No medial or intimal changes

Grade I: Medial thickness more than 2 but less than 4 layers thick

Grade II: Medial thickness more than 4 but less than 6 layers thick

Grade III: Medial thickness more than 6 layers thick

Grade IV: Intimal changes

\section{Statistical Analysis}

Statistical analysis was done using STATA 9.0 software (Stata Corp, College Station, Tex). Continuous and interval-related data are presented as mean \pm standard deviation. Categorical variables are expressed as frequency distribution and percentages. Comparisons between the groups for continuous variables have been analyzed using the Student $t$ test/Wilcoxon rank sum test. Spearman rank correlation was calculated to assess the strength of relationship between quantitative variables. The $\chi^{2}$ test has been used to assess the association between independent and outcome variables. Multivariate logistic regression was performed to calculate the odds ratio and the $95 \%$ confidence interval $(\mathrm{CI})$ for each independent variable.

\section{RESULTS}

To identify a predictive factor, if any, we correlated the histomorphometric findings against 2 different operations, patient demographics, preoperative and postoperative hemodynamics, early outcome after surgery, and lung biopsy findings. Four (26.6\%) of 15 patients undergoing TCPC had poor outcome defined as Fontan takedown, low cardiac output, and $\mathrm{SaO}_{2}$ less than $75 \%$. Three $(10.3 \%)$ of 29 patients undergoing SCPC died in the immediate postoperative period owing to persistently raised PAP despite using pulmonary vasodilators and interrupting the antegrade pulmonary blood flow.

\section{Relationships Between Morphohistometric Measurements and Type of Operations}

The values of mean, smallest, and largest indexed intraacinar PA area, diameter, intimal thickness, media/intima ratio, and density were compared between 2 groups of patients (Table E2; Figures E2 to E7). It is noteworthy that only the mean indexed diameter of the intra-acinar PAs was significantly different between 2 groups of patients $(P=.03)$.

\section{Relationships Between the Histomorphometrically Derived Parameters and Patient Demographics}

A significant correlation existed between the histomorphometric parameters and age, body weight, and body surface area of all patients undergoing SCPC and TCPC (Tables E3).

There was no demonstrable correlation between the histomorphometric parameters and increased aortic diameter $(>24.80 \mathrm{~mm})$, right aortic arch, anomalous systemic venous drainage, major aortopulmonary collateral arteries, atrial isomerism, systemic-PA shunt, PA band, cardiac morphology, and atrioventricular valve regurgitation of patients undergoing either SCPC or TCPC.

However, among patients undergoing TCPC, the mean indexed area of the intra-acinar arteries was significantly related to the presence of aortic regurgitation $(P=.04)$ and patients requiring concomitant pulmonary arterioplasty $(P=.01)$.

\section{Relationships Between the Histomorphometrically Derived Parameters and Preoperative Hemodynamic Variables}

Preoperatively, the mean PAP in patients undergoing TCPC and SCPC was $15.33 \pm 1.95$ and $14.62 \pm 4.29 \mathrm{~mm}$ $\mathrm{Hg}$, respectively, and $15(34.1 \%)$ patients had mean PAP greater than $15 \mathrm{~mm} \mathrm{Hg}$. There was no statistically significant relationship between histomorphometric parameters of the intra-acinar PAs and SVEDP, systemic ventricular ejection fraction, mean PAP, PVR, pulmonary/systemic flow ratio, and Nakata PA index values among patients undergoing TCPC (Table E4).

Similarly, no relationships were observed between these histomorphometric values and systemic ventricular ejection fraction, SVEDP, mean PAP, PVR, and pulmonary/systemic flow ratio in patients undergoing SCPC (Table E4).

However, there were significant correlations between $\mathrm{Na}-$ kata PA index and mean indexed area of the intra-acinar PAs $(r=-0.76 ; P=.006)$, indexed diameter and medial thickness of the intra-acinar PAs, and pulmonary/systemic flow ratio $(r=-0.041 ; P=.02 ; r=-0.39 ; P=.03)$ of patients undergoing SCPC (Table E4).

\section{Relationships Between Morphohistometric Measurements and Early Outcome}

Patients undergoing either SCPC or TCPC with a Nakata PA index less than 200 units $/ \mathrm{m}^{2}$ and PVR greater than 2 Wood units $/ \mathrm{m}^{2}$ were at $9.61 \quad(95 \%$ CI: 1.01-91.15; $P=.003)$ and 8.5 (95\% CI: $1.26-57.19 ; P=.04)$ times increased risk of death after surgery. None of the histomorphometric values achieved statistical significance when compared with the outcomes after either SCPC or TCPC, respectively (Tables E5 and E6).

\section{Relationships Between the Preoperative and Postoperative Hemodynamic Variables and Outcome After Surgery}

Among patients undergoing TCPC, only Nakata PA index less than $200 / \mathrm{mm}^{2}$ was related to poor outcome after surgery 
$(331.36 \pm 63.28$ vs $190 \pm 49.65 ; P=.006)$. This possibly is because of stringent candidate selection for patients undergoing TCPC (Table E7).

Among patients undergoing SCPC, raised SVEDP $(>12 \mathrm{~mm} \mathrm{Hg})$, increased mean PAP $(>15 \mathrm{~mm} \mathrm{Hg})$, and raised postoperative superior and inferior vena caval pressure $(>12 \mathrm{~mm} \mathrm{Hg})$ were not significantly related to adverse outcome after surgery. The PVR in patients dying after SCPC $(\mathrm{n}=3)$ was between 2.6 and 3.0 Wood units $/ \mathrm{m}^{2}$ (mean, $2.73 \pm 0.23$ ) and was significantly related to poor outcome after SCPC (Table E7).

\section{Relationships Between the Histomorphometrically Derived Measurements and Presence of Intimal Lesions, Intra-Acinar Arterial Thrombus, Abnormal Smooth Muscle Extension, and Intra-PA Fibrosis/ Chronic Inflammatory Interstitial Cells}

There was significant correlation between mean indexed intimal thickness and the presence of intimal lesions $(P=.03)$, presence of interstitial cells, and indexed media/intima ratio $(P=.05)$. The mean indexed vascular density of the intra-acinar PAs ranged between 3 and $8 / \mathrm{mm}^{2}$ (TCPC: $5.06 \pm$ 1.53 vs SCPC: $5.41 \pm 1.43$ ). There was no difference in vascular density between the 2 groups of patients undergoing either SCPC or TCPC. It was not related to good or poor outcome after surgery and was unrelated to all preoperative demographics, including cardiac morphology. However, the intra-acinar vascular density was more in the presence of abnormal smooth muscle extension $(6.37 \pm 1.3$ vs $5.04 \pm 1.32$; $P=.03$ ) in patients undergoing SCPC. All patients with poor outcome after TCPC had demonstrable intimal lesions $(P=.009)$, intra-acinar PA thrombus $(P=.05)$, and abnormal smooth muscle extension of the intra-acinar PAs. There was no significant relationship between these abnormal histopathologic findings and outcome after SCPC (Figures E5 to E7).

\section{Relationship Between Preoperative and \\ Postoperative Hemodynamic Variables and Lung \\ Biopsy Findings of the Intra-Acinar PAs}

In addition to the medial thickness, intimal thickness, and density of the intra-acinar PAs, we analyzed intrapulmonary vascular intimal lesions, intra-acinar PA thrombus, intra-PA smooth muscle extension, and the presence of intrapulmonary chronic inflammatory cells, if any.

Overall, there were $8(8.2 \%), 4(9.1 \%), 13(29.5 \%)$, and $29(65.9 \%)$ instances of intra-PA intimal lesions, thrombosis, smooth muscle extension, and interstitial fibrosis in this study group (Tables E7 to E9; Figures E5 to E7).

Among patients undergoing TCPC, only low Nakata index was significantly associated with the presence of intimal lesions $(P=.009)$, intra-PA smooth muscle extension $(P=.01)$, intra-PA thrombus $(P=.04)$, and the presence of chronic inflammatory cells. By contrast, among patients undergoing SCPC, only raised PVR ( $>2$ Wood units $\left./ \mathrm{m}^{2}\right)$ was associated with the presence of intrapulmonary intimal lesions $(P=.03)$ (Tables E8 and E9).

\section{DISCUSSION}

So far as we aware, there have been only 9 published studies (autopsy series, $\mathrm{n}=6$; surgical series, $\mathrm{n}=3$ ) in the literature addressing specifically the histopathology and/or morphometry of the intrapulmonary vessels in patients undergoing univentricular repair, with contradictory results. ${ }^{\text {E1-E4,E9-E13 }}$

Previous studies have been mainly concerned with analyzing structural features of fatal cases ${ }^{\mathrm{E} 1 \mathrm{E} 2}$ or biopsy material obtained at a palliative procedure rather than those obtained during physiologic repair. ${ }^{\mathrm{E} 2 \mathrm{E} 3}$ Patients who have died because of definite technical problems have not been excluded from analysis of outcome. ${ }^{\text {E1-E4,E9-E15 }}$

\section{The Principal Findings of This Investigation}

1. The existence of severe intimal lesions, abnormal smooth muscle extension onto the intra-acinar PAs, and intra-acinar PA thrombus in patients with poor outcome after TCPC

2. A statistically significant interrelationship between low Nakata PA index and the concomitant presence of severe intimal lesions, abnormal smooth muscle extension onto the intra-acinar PA, and intra-acinar PA thrombus in patients with poor outcome after TCPC

3. The finding of a smaller mean indexed area of the intra-acinar PAs in patients requiring concomitant pulmonary arterioplasty

4. The presence of intra-acinar PA thrombi in patients with low pulmonary blood flow despite qualifying the selection criteria for a Fontan operation

Although a lung biopsy specimen may not represent the status of the whole lung because of differential flows in the lungs of patients with univentricular physiology, it was always abnormal in cases of failure after TCPC or SCPC. Second, the present study shows that structural abnormality in the intrapulmonary vasculature may increase the risk of operation in patients fulfilling the criteria for a univentricular repair or who have a modest increase in PVR over the recommended level. Most of the published studies reported essentially status of the proximal arteries (preacinar small PAs) and did not mention the status of distal intra-acinar small PAs.

The findings in the present study suggest that in patients with single ventricle physiology with a reduced pulmonary blood flow, the PA structure is almost normal and unlikely to prejudice the outcome of a Fontan repair, although thrombotic occlusion of small PAs is possible. By contrast, in those with an excessive pulmonary blood flow in the preoperative period, even when the PVR is slightly raised, there may be a significant increase in PA muscularity resulting in increased PVR and increased right atrial afterload 
immediately after surgery. The risk of a Fontan type of repair is probably greater in these patients than in patients with low pulmonary blood flow preoperatively, but in this group a preoperative lung biopsy may help in selecting patients for repair.

The critical question is whether tissue obtained at lung biopsy contains sufficient material for structural analysis of the lung. A section of lung periphery contains many small arteries less than $300 \mu \mathrm{m}$ in diameter, and it is in these vessels that muscle cells first appear or hypertrophy when pulmonary hypertension occurs or, in the experimental animal, on exposure to hypoxia. ${ }^{\mathrm{E} 1-\mathrm{E} 4, \mathrm{E} 9-\mathrm{E} 21}$ As yet, there is no foolproof formula for choosing an optimal location of lung biopsy in an individual patient undergoing univentricular repair. In this study, we have avoided taking biopsy specimens from the lingular lobe inasmuch as it tends to have thicker arterial walls than other regions of the lung.*

What Are the Potential Risk Factors Responsible for Fontan Failure Among Ideal Candidates from the Standpoint of Hemodynamic Data?

Is Nakata PA Index an Accurate Predictor of Outcome after Fontan-type Operations?

Published literature does not provide any conclusive answer. $^{\dagger}$ Despite fulfilling the indications based on hemodynamic data and PA size, a subset of patients in the postoperative period has low cardiac output and extracellular fluid accumulation resistant to medical treatment after Fontantype operations. Despite having an unobstructed, unrestricted Fontan pathway and fenestrated atrial baffle, a subset of patients died after surgery. ${ }^{\text {E1-E5 }}$ Although high PVR resulting in failure in the postoperative period may be attributable to microvascular changes in the pulmonary vascular bed, ${ }^{\text {E1-E3,E9,E10,E14-E17 }}$ the role of lung biopsy in decision-making for Fontan-type operations has remained controversial because they are not associated with variables that differentiate between patients with good and poor outcomes. $^{\mathrm{E} 1, \mathrm{E} 2, \mathrm{E} 9}$

Incidentally, the outcomes for the 44 patients included in this study were worse than the published results from other centers with a $10 \%$ mortality rate after SCPC and $26.6 \%$ "poor" outcome after TCPC. Inasmuch as late presentation of congenital heart disease is not unusual in the developing world, it is not uncommon to be faced with the grown-up patient with a functionally univentricular heart with or without previous palliation. Such patients are more cyanotic and polycythemic and are indeed a different subset from those encountered in the Western world.

In this study group, despite a mean age of $83.52 \pm 75.90$ months, only $17(38.6 \%)$ patients were shunted, $38(86.3 \%)$ had hematocrit values greater than $45 \%, 37(84 \%)$ had

\footnotetext{
*References E1, E2, E9, E10, E14, E16, E17, E19.

${ }^{\dagger}$ References E1-E5, E9-E12, E14, E16, E17.
}

$\mathrm{SaO}_{2} \mathrm{~S}$ less than $80 \%, 15(35 \%)$ had elevated PAPs of more than $15 \mathrm{~mm} \mathrm{Hg}$, and $14(31.8 \%)$ had SVEDPs of more than $12 \mathrm{~mm} \mathrm{Hg}$. Given the wide ranges of ages, chronic cyanosis, or long-term volume overload of the systemic ventricle, raised SVEDP $(P=.04)$ and PAP $(P=.01)$ played a significant role in these poor outcomes. Among patients undergoing SCPC, raised PVR $\left(>2\right.$ Wood units $\left./ \mathrm{m}^{2}\right)$ was associated with the presence of intrapulmonary intimal lesions $(P=.03)$ and poor outcome after surgery $(P=.007)$.

Despite a functioning systemic-PA shunt and normal origin of the PAs without bifurcation stenosis or in the presence of adequate PA flow or both, 18 (41\%) patients in this study group had borderline Nakata index for univentricular repair. Overall, patients with low Nakata index were associated with 9.61 (95\% CI: $1.01-91.15 ; P=.003)$ times increased risk of death after surgery despite undergoing surgical enlargement.

Among patients undergoing TCPC, only low Nakata index was significantly associated with the presence of intimal lesions $(P=.009)$, intra-PA smooth muscle extension $(P=.01)$, intra-PA thrombus $(P=.04)$, and the presence of chronic inflammatory cells. All patients with poor outcome after TCPC had demonstrable intimal lesions $(P=.009)$, intra-acinar PA thrombus $(P=.05)$, and abnormal smooth muscle extension of the intra-acinar PAs. By contrast, among patients undergoing SCPC, only raised PVR ( $>2$ Wood units/ $\mathrm{m}^{2}$ ) was associated with the presence of intrapulmonary intimal lesions $(P=.03)$ (Tables E8 and E9).

In our study, none of the histomorphometrically derived parameters could conclusively predict the outcome after univentricular repair. One reason for this is that all of our patients were considered to be Fontan or bidirectional Glenn candidates on the basis of hemodynamic data. Therefore, there exists the possibility that patients with severe intimal lesions/advanced Heath-Edwards grade were excluded from the study group. Second, the Heath-Edwards grade is determined by the severest lesion in the section. Therefore, the presence of a single vessel with severe lesion will be labeled as having advanced Heath-Edwards grade. As pointed out by other investigators, Heath-Edwards grading does not represent the general status of the pulmonary vascular bed. ${ }^{\text {E17 }}$ Therefore, we formulated the morphometric grades as mentioned earlier and applied the same on all study samples.

\section{Study Limitations}

The principal limitation of the study is that we examined histologically only a small peripheral segment of the lung tissue. With the current techniques of histomorphometric analysis of the lung tissue, a prohibitively large number of samples from different parts of the lung are required to determine the histologic indication for Fontan-type operations.

Second, the population considered in this study is highly heterogenous and the number of patients in each subgroup 
is small. Third, it remains uncertain whether these demonstrable changes are uniform throughout the lung on both sides.

Finally, owing to the small number of adverse events after surgery, we could not determine any cutoff value of the histomorphometrically derived variables, namely, the mean indexed area, diameter, medial thickness, intimal thickness, media/intima thickness ratio, and the mean indexed density of intra-PAs. Larger scale histomorphometric analyses of the lung tissue are required in decision-making for better selection of Fontan-type operations.

\section{Clinical Implications and Recommendations}

The present study indicates the preponderance of severe intimal lesions, thrombus, and abnormal smooth muscle extension onto the intra-acinar PAs in patients with poor outcome after TCPC.

Despite surgical enlargement of the intrapericardial PAs, this subset of patients continued to exhibit poor outcome and was associated with a lower mean indexed area of the intra-PAs $(P=.01)$.

Therefore, histomorphometric studies may be a useful method of supplementing a variety of clinical data in the following clinical situations:
1. Re-evaluation of patients who are considered borderline candidates for univentricular repair on the basis of catheterization data

2. Decision to take down a Fontan circuit because of Fontan failure

3. Selection of patients for a single-stage or 2-stage Fontan operation by doing intraoperative lung biopsy

\section{CONCLUSIONS}

We conclude that none of the histomorphometrically derived parameters from lung tissue, namely, the indexed intra-PA area, diameter, medial thickness, intimal thickness, and vascular density, can conclusively predict the outcome after Fontan-type operations. Hemodynamic variables are influenced by methods of measurement and the patient's clinical condition and they do not perfectly represent the status of the intrapulmonary vasculature. However, a low Nakata index is significantly associated with the presence of intra-PA lesions, smooth muscle extension, and intra-acinar thrombus and is associated with poor outcome after TCPC.

Therefore, although the intrapericardial PAs are surgically enlargeable, a borderline candidate for TCPC with a low Nakata index should not be subjected to 1-stage univentricular repair. 


\section{E-APPENDIX 1. Definitions}

\section{Description of a Small PA or Large Pulmonary Arteriole}

This group of arteries or arterioles has a luminal diameter of 0.3 to $0.5 \mathrm{~cm}$. Their wall thickness is usually low in comparison with their overall diameter. It comprises the following 3 layers:

- Tunica intima - only comprises a thin, flattened layer of endothelial cell

- Tunica media—normally comprises only 2 to 3 layers of smooth muscle cells

- Tunica adventitia - comprises loose collagenous tissue of moderate thickness

Any morphologic deviation from these definitions was taken into account and categorized accordingly.

Within the vascular lumen, any evidence of thrombus (either fresh fibrin thrombus or organized thrombus) was noted, and to this purpose all arterioles in the section were examined. In addition, evidence of inflammatory cell infiltrate, fibrosis, or muscularization was noted. Any evidence of fresh or old alveolar hemorrhages was taken into account. For confirmation of medial thickness, intimal fibrosis, or interalveolar septal fibrosis, the following special stains were performed:

- Voerhoff's van Giesan stain for elastic tissue (black)

- Masson's trichrome stain for fibrosis/collaginization (blue) or muscularization (reddish-brown)

The arteriolar changes were graded as follows:

Grade 0: Normal arterial structure and number for age

Grade A: Muscularization of normally nonmuscular intraacinar arteries

Grade B: Medial hypertrophy greater than $1.5 \times$ normal for uninjected or barium-injected samples

Grade C: Decreased peripheral arterial density relative to alveolar number for age.

For biopsy specimens assigned grade $\mathrm{B}$ or $\mathrm{C}$, features of the preceding grade were fulfilled except in 2 specimens assigned grade $\mathrm{C}$. In these cases, arterial concentration was decreased in the presence of abnormal extension of muscle but without medial hypertrophy.

It is not adequate for an evaluation of the extent to which pulmonary vascular disease is present throughout the arterial system of individual cases, since the Heath-Edwards classification depends on a fortuitous selection of arterial sections with severe histologic changes. ${ }^{\text {E17 }}$ Different grades of arterial changes are usually observed even within a given case. Bronchial arteries were of course excluded from the examination.

\section{Density of Pulmonary Arterioles}

Corrected density of small PAs was determined as follows. The number of small PAs per square centimeter having a diameter greater than $100 \mu \mathrm{m}$ was counted by a method described by Takahashi and colleagues. ${ }^{\text {E18 }}$ This value indicates the density of small PAs in a histologic section and is corrected by the number of alveolar septa intersected by a test line of sufficient length drawn on the section to exclude the influence of the degree of lung collapse.

\section{Technique of Histologic Processing (Routine Paraffin Block Preparation)}

At our institute, we use an automated Histotech tissue processor for processing of the histopathologic sections. The bucket with the cassettes containing appropriate tissue sections are at first put into the buckets of the Histotech machine for the purpose of dehydration. This step is undertaken to remove the water with alcohol and xylene and to replace the vacuum by wax. For this purpose, the formalin is first washed out followed by treatment of the section in graded concentration of alcohol (buckets of 70\%, 95\%, 100\%, and $100 \%$ alcohol, respectively). The water is replaced by diffusion. The time taken in each bucket can be fixed manually as per the standard of the histopathology laboratory.

After this step, the tissue section is put in a bucket containing xylene for the purpose of "clearing," that is, this process makes the tissue quite transparent and the fat solvent is permitted to percolate into the pores of the tissue.

After this, the tissue section is bathed into 2 buckets of liquid wax $\left(55^{\circ} \mathrm{C}\right)$, where the liquid wax penetrates the tissue pores by replacing the xylene. Thus finally the tissue section that is processed overnight is transparent, resilient, and permanent as the water molecules in between the tissue spaces are replaced by wax, which also provides hardness necessary for cutting it in the microtome.

The prepared section is then placed in a paraffin block to give it sufficient external support for cutting in the microtome. The section is oriented inside the paraffin block as instructed by the investigator. The block is made in another semiautomated embedding station equipped with automated liquid wax dispenser and hot and cold plates.

\section{Technique of Slide Preparation}

After the block is prepared, it is trimmed for convenience of fitting it in a microtome. Both the forward and lateral surfaces are trimmed. Thereafter, the block is kept in direct contact with ice for at least 1 hour to harden the tissue and wax further for proper cutting. After the block has been fitted in the block holder of the microtome, the sections are cut (4-5 $\mu$ m thick).

The sections are then floated carefully on a water bath with a desired temperature of $52^{\circ} \mathrm{C}$ to $56^{\circ} \mathrm{C}$. This procedure flattens the cut section and permits proper mounting of the section on a glass slide without any fold. The glass slides are usually precoated with egg albumin for proper fixation 
of the section on it. After being put on the glass slide, the section is properly labeled with a diamond marker.

The slides with sections are then heated at $60^{\circ} \mathrm{C}$ to $65^{\circ} \mathrm{C}$ for 5 to 10 minutes and put at once in xylene to remove the paraffin cut along with it. They are then dipped in decreasing grades of alcohol and last put in water for rehydration, as all the routine histopathology stains available are water soluble.

\section{Technique of Staining the Slides (Routine Hematoxylin and Eosin Staining)}

The hematoxylin and eosin stain is applied as a routine. It comprises a basic dye, hematoxylin, which stains the basophilic structures of a cell such as DNA and RNA, and the acid dye, eosin, which stains the acidophilic (eosinophilic) structures of a cell such as mitochondria and collagen. The staining is also done by an automated stainer comprising slide racks, stains, and chemicals for dehydration and clearing of the slides.

The hematoxylin stain is extracted from the logwood of the tree Hematoxylon campechianum (origin in the Mexican state of Campeche). It is then ripened to hematin by an oxidizing agent and made permanent by using a mordant (a metal cation). Many mordants can be used, but commonly aluminium is used in Harris's hematoxylin that is used for routine staining in our laboratory. The steps of staining are as follows:

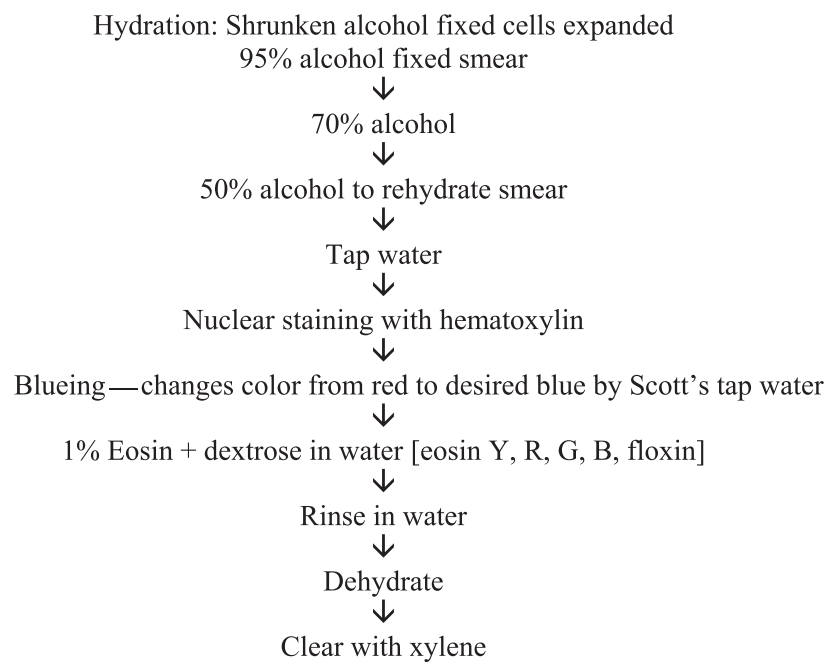

The sections are then mounted with coverslip by mounting medium-DPX (diathreme pthalate xylene).

\section{Image Morphometry}

Before image analysis was started, the software scales were calibrated for $20 \times$ objective by using a precalibrated commercially acquired glass slide designed specially for calibration of Image-Pro Plus 6 software (Media Cybernetics, Silver Spring, Md).

A CoolSNAP-Pro Color (Media Cybernetics) CCD camera was used to take digital images. The photographs were saved in the JPEG (Joint Photographics Expert Group) format, ISO-10918-1, with quality set to $100 \%$ and using "Baseline (Standard)" compression algorithm.

The photographs were then edited in Microsoft Office Picture Manager version 12.0.4518.1014, part of Microsoft Office 2007, released in 2006 (Microsoft Corporation, Redmond, Wash). Brightness, contrast, and mid-tone corrections were applied manually to all the slide photographs to render the image satisfactory for image morphometry.

The JPEG format picture of all smaller PAs/larger arterioles was then opened in this software window, where the digital image was converted into pixelate form and various dimensions were measured by given scales (Figure E1, $A$ to $C$ ). With the help of this software, the following parameters were measured: circumferential area, total diameter, medial thickness, and intimal thickness.

The same parameters were looked for in all 20 selected arterioles. Bronchial arteries were deliberately excluded from this study. Only the arteries/arterioles accompanying the secondary or tertiary airways were selected for study. The measured dimensions were then tabulated in an Excel sheet and a mean value \pm standard deviation was calculated out of each parameters.

Circumferential area. All layers of the PAs/arterioles were included in the measurement (Figure E1,B).

Total diameter. Total diameter was measured in the largest axis of the arteries, spanning between the extreme outer point of tunica adventitia at one pole of the axis to the extreme outer most point of adventitia in the other pole of axis (Figure E1, $B$ ).

Intimal thickness. Only the thickness of endothelium was measured in normal condition. In the presence of intimal proliferation, total intimal and subintimal area up to the muscle layer was measured (Figure E1, C).

Medial thickness. The total thickness of smooth muscle layer was measured. For this purpose, the arteries that were obliquely cut were excluded (Figure E1, C).

\section{Assessment of Operative Outcome}

Outcome variables assessed after TCPC were Fontan failure and postoperative pleural effusion apart from mortality. Fontan failure was defined as a persistently low cardiac output after univentricular repair, with a need to maintain central venous pressure at $18 \mathrm{~mm} \mathrm{Hg}$ or higher and/or inordinately high fluid requirement to maintain acceptable cardiac output, and it included all patients who died within 30 days of the operation as well as those who required Fontan takedown. Low output syndrome was diagnosed if the patient required inotropic support (dopamine [4-10 $\mu \mathrm{g}$. $\left.\mathrm{kg}^{-1} \cdot \min ^{-1}\right]$, dobutamine $\left[5-10 \mu \mathrm{g} \cdot \mathrm{kg}^{-1} \cdot \mathrm{min}^{-1}\right]$, epinephrine $\left[0.01-0.1 \mu \mathrm{g} \cdot \mathrm{kg}^{-1} \cdot \mathrm{min}^{-1}\right]$, milrinone [50 $\mu \mathrm{g} /$ $\mathrm{kg}$ intravenous bolus followed by $0.375-0.75 \mu \mathrm{g} \cdot \mathrm{kg}^{-1}$. $\left.\min ^{-1}\right]$ ), either isolated or in combination, in the operating room or in the intensive care unit to maintain stable 
hemodynamics in the absence of residual structural lesions and mechanical external compression after correction of all electrolytes or blood gas abnormalities and after adjusting the preload to its optimal value. Low output syndrome was also diagnosed if there was an increasing requirement of the aforementioned inotropes along with afterload reduction with sodium nitroprusside. Patients who received less than $4 \mu \mathrm{g} \cdot \mathrm{kg}^{-1} \cdot \min ^{-1}$ of dopamine to increase renal perfusion were not considered to have low output syndrome.

Invasive monitors to measure cardiac output directly (Swan-Ganz catheter [Edwards LifeSciences, Irvine, Calif], PA pressure line, and thermistors) are cumbersome and hazardous in children and are generally avoided in our setup except in complex cases. We generally limit intracardiac monitoring to right and left atrial pressure lines.

Accordingly, under the definition of low output syndrome after univentricular repair, an integration of relevant clinical, laboratory and bedside echocardiographic criteria were used. The criteria for diagnosis were as follows: cold extremities, absent pedal pulses, decreased toe temperature, reduced systolic pressure, impaired renal function and oliguria $\left(<1.0 \mathrm{~mL} \cdot \mathrm{kg}^{-1} \cdot \mathrm{h}^{-1}\right)$, metabolic acidosis, increased serum lactate levels $(\geq 2.0 \mathrm{mmol} / \mathrm{L}, \geq 2$ hours), low mixed venous oxygen saturation $(\leq 50 \%)$, and blunt sensorium. Any pleural effusion that lasted for more than 10 days after the operation or recurrent effusion after chest tube removal was included as significant pleural effusion.

Good outcome included patients who survived the operation and are doing well. Poor outcome included patients who died after surgery or who required Fontan takedown in the immediate postoperative period.

Criteria for poor outcome after SCPC included patients who died after surgery owing to the development of superior vena caval syndrome with persistently high PAP, unresponsive to pulmonary vasodilators including nitric oxide, and persistent cyanosis $\left(\mathrm{SaO}_{2}: 60 \%-65 \%\right)$ in the presence of an unrestricted anastomosis.

\section{E-References}

E1. Juaneda E, Haworth SG. Pulmonary vascular structure in patients dying after a Fontan procedure. The lung as a risk factor. Br Heart J. 1984;52:575-80.

E2. Juaneda E, Haworth SG. Double inlet ventricle: lung biopsy findings and implications for management. Br Heart J. 1985;53:515-9.
E3. Caspi J, Coles JG, Rabinovich M, Cohen D, Trusler GA, Williams WG, et al. Morphological findings contributing to a failed Fontan procedure. Twelveyear experience. Circulation. 1990;82(5 Suppl):IV177-82.

E4. Masuda M, Kado H, Shiokawa Y, Fukae K, Suzuki M, Murakami E, et al. Clinical results of the staged Fontan procedure in high-risk patients. Ann Thorac Surg. 1998;65:1721-5.

E5. Knott-Craig CJ, Danielson GK, Schaff HV, Puga FJ, Weaver AL, Driscoll DD. The modified Fontan operation: an analysis of risk factors for early postoperative death or takedown in 702 consecutive patients from one institution. J Thorac Cardiovasc Surg. 1995;109:1237-43.

E6. Chowdhury UK, Mishra PK, Sharma R, Airan B, Subramaniam GK, Kothari SS, et al. Postoperative assessment of the univentricular repair by dynamic radionuclide studies. Ann Thorac Surg. 2004;78:658-65.

E7. Chowdhury UK, Airan B, Kothari SS, Talwar S, Saxena A, Singh R, et al. Specific issues after extracardiac Fontan operation: ventricular function, growth potential, arrhythmia, and thromboembolism. Ann Thorac Surg. 2005;80:665-72.

E8. Bridges ND, Farrell PE Jr, Pigott JD 3rd, Norwood WI, Chin AJ. Pulmonary artery index: a nonpredictor of operative survival in patients undergoing modified Fontan repair. Circulation. 1989;80(3 Pt 1):I216-21.

E9. Geggel RL, Mayer JE Jr, Fried R, Helgason H, Cook EF, Reid LM. Role of lung biopsy in patients undergoing a modified Fontan procedure. J Thorac Cardiovasc Surg. 1990;99:451-9.

E10. Yamaki S, Ajiki H, Haneda K, Takanashi Y, Ban T, Takahashi T. Pulmonary arterial changes in patients dying after a modified Fontan procedure following pulmonary artery banding. Heart Vessels. 1994;9:263-8.

E11. Levy M, Danel C, Tamisier D, Vouhé P, Leca F. Histomorphometric analysis of pulmonary vessels in single ventricle for better selection of patients for the Fontan operation. J Thorac Cardiovasc Surg. 2002;123:263-70.

E12. Rosenberg HC, Coles JG, Williams WG, Trusler GA, Rabinovitch M. An association between vascular changes on lung biopsy specimens and postoperative morbidity following the Fontan procedure [abstract]. J Am Coll Cardiol. 1987;9:204A.

E13. Rabinovitch M, Sanders SP, Castaneda AR, Reid L. Morphometric analysis of lung biopsy tissue in candidates for Fontan-type surgical procedure [abstract]. Am J Cardiol. 1981;47:447.

E14. Rabinovitch M, Castaneda AR, Reid L. Lung biopsy with frozen section as a diagnostic aid in patients with congenital heart defects. Am J Cardiol. 1981;47: 77-84.

E15. Olson TM, Driscoll DJ, Edwards WD, Puga FJ, Danielson GK. Pulmonary microthrombi: caveat for successful modified Fontan operation. J Thorac Cardiovasc Surg. 1993;106:739-44.

E16. Fisher DJ, Geva T, Feltes TF, Cecchin F, Nihill MR, Grifka R, et al. Lifelong management of patients with a single functional ventricle: a protocol. Tex Heart Inst J. 1995;22:285-95.

E17. Heath D, Edwards JE. The pathology of hypertensive pulmonary vascular disease: a description of six grades of structural changes in the pulmonary arteries with special references to congenital cardiac septal defects. Circulation. 1958; 18:533-47.

E18. Takahashi T, Wagenvoort N, Wagenvoort CA. The density of muscularized pulmonary arteries in normal lungs. Arch Pathol Lab Med. 1983;107:19-22.

E19. Haworth SG, Reid L. A morphometric study of regional variation in lung structure in infants with pulmonary hypertension and congenital cardiac defect: a justification of lung biopsy. Br Heart J. 1978;40:825-31.

E20. DeLeon SY, Ilbawi MN, Idriss FS, Muster AJ, Gidding SS, Berry TE, et al. Persistent low cardiac output after the Fontan operation: should take down be considered? J Thorac Cardiovasc Surg. 1986;92:402-5.

E21. Yamaki S, Tezuka F. Quantitative analysis of pulmonary vascular disease in complete transposition of the great arteries. Circulation. 1976;54:805-9. 


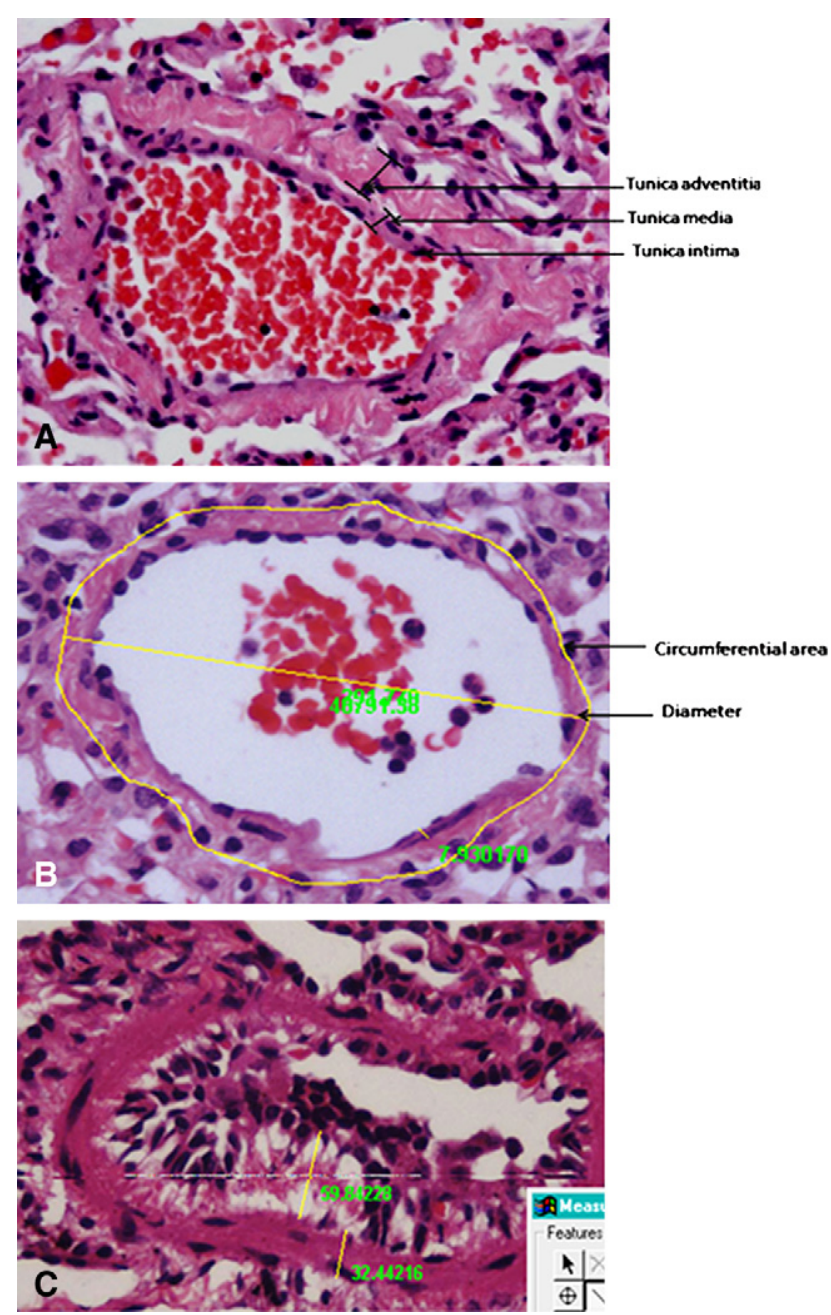

FIGURE E1. Photomicrograph of lung biopsy specimen of patients undergoing univentricular repair showing 3 layers of a small intra-acinar pulmonary artery (A), morphometric measurements of circumferential area incorporating all 3 layers, diameter from one advential margin to the opposite advential margin (B), and endothelial versus medial thickness, where endothelial layer is markedly thickened with subendothelial edema (C). 


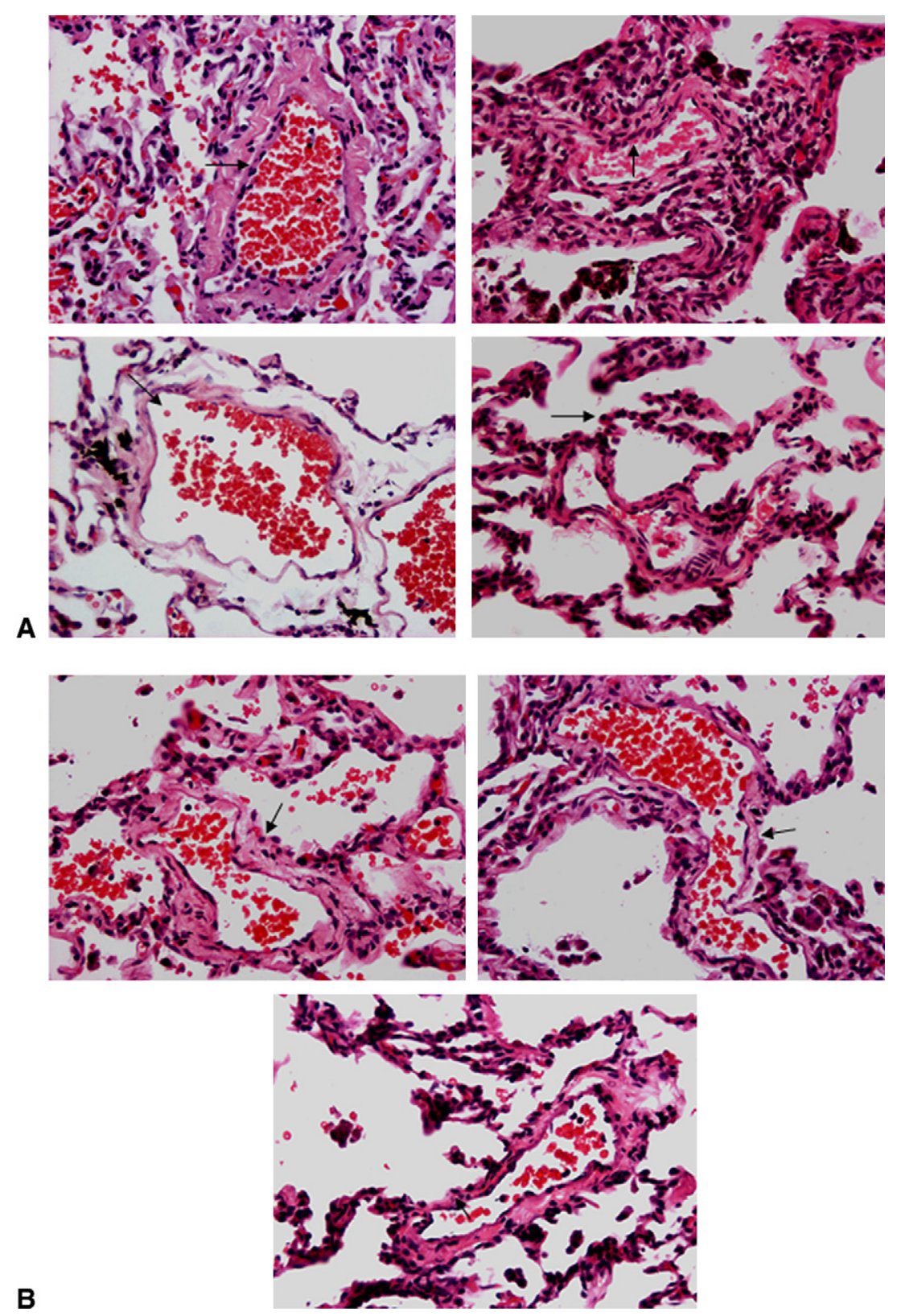

FIGURE E2. A, Photomicrographs of the lung biopsy specimen of patients with tricuspid atresia showing normal 3 layers of a small intra-acinar pulmonary artery (hematoxylin and eosin stain, original magnification $\times 200$ ). B, Photomicrographs of lung biopsy specimen of patients with functionally univentricular heart showing normal 3 layers of a small intra-acinar pulmonary artery (hematoxylin and eosin stain, original magnification $\times 200$ ). 

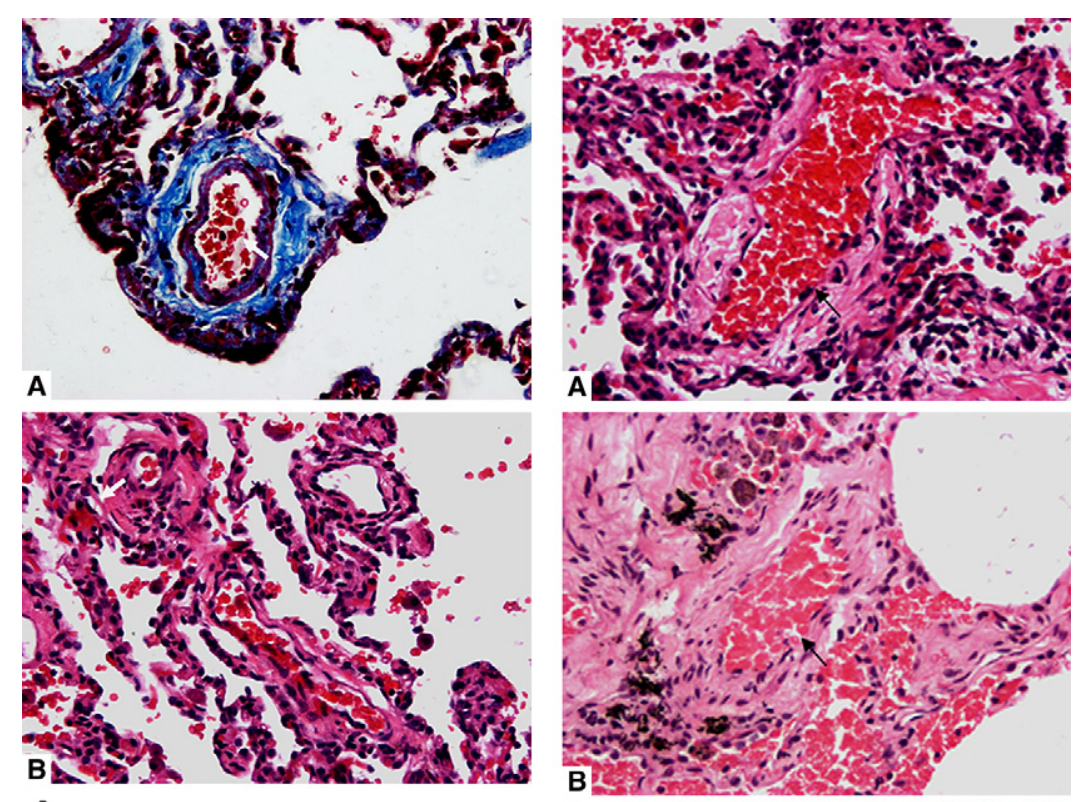

A

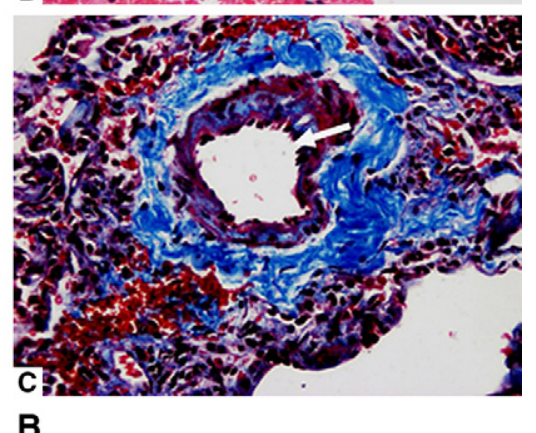

FIGURE E3. A, Photomicrograph of the lung biopsy specimen of a patient with tricuspid atresia showing mild medial hypertrophy of a small intra-acinar pulmonary artery (A, Masson's trichrome stain, original magnification $\times 200$; B, hematoxylin and eosin stain, original magnification $\times 200$ ). B, Photomicrographs of lung biopsy specimen of patients with functionally univentricular heart showing mild medial hypertrophy of a small intra-acinar pulmonary artery (A, B, hematoxylin and eosin stain, original magnification $\times 200$; C, Masson's trichrome stain, original magnification $\times 200$ ).

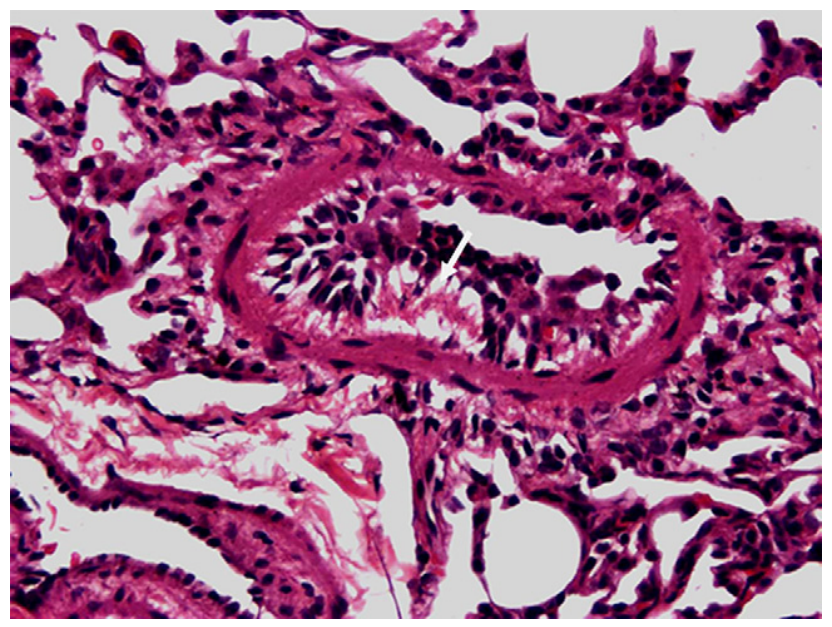

FIGURE E4. Photomicrograph of lung biopsy specimen of a patient with a functionally univentricular heart showing intimal thickening and subendothelial edema of a small intra-acinar pulmonary artery (hematoxylin and eosin stain, original magnification $\times 200$ ). 


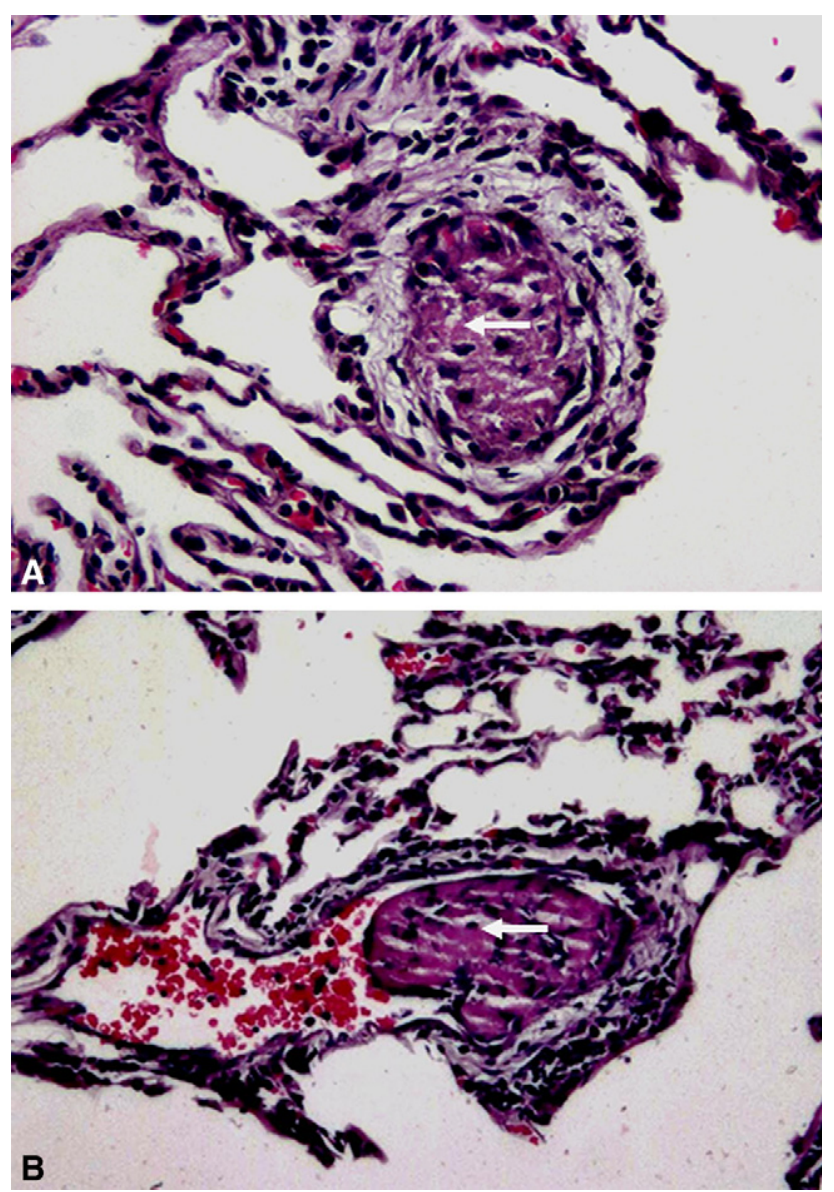

FIGURE E5. Photomicrographs of lung biopsy specimen of patients with tricuspid atresia showing fresh intraluminal fibrin thrombus (A) and organizing intraluminal thrombus (B) of a small intra-acinar pulmonary artery (hematoxylin and eosin stain, original magnification $\times 200$ ).

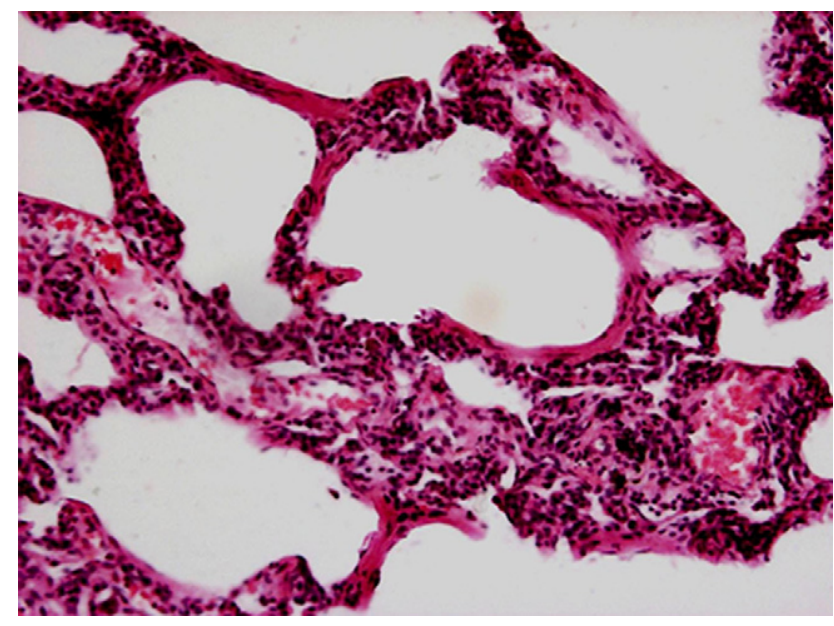

FIGURE E7. Photomicrographs of lung biopsy specimen of patients with tricuspid atresia showing muscularization of distal small intra-acinar pulmonary arteries (hematoxylin and eosin stain, original magnification $\times 200$ ).

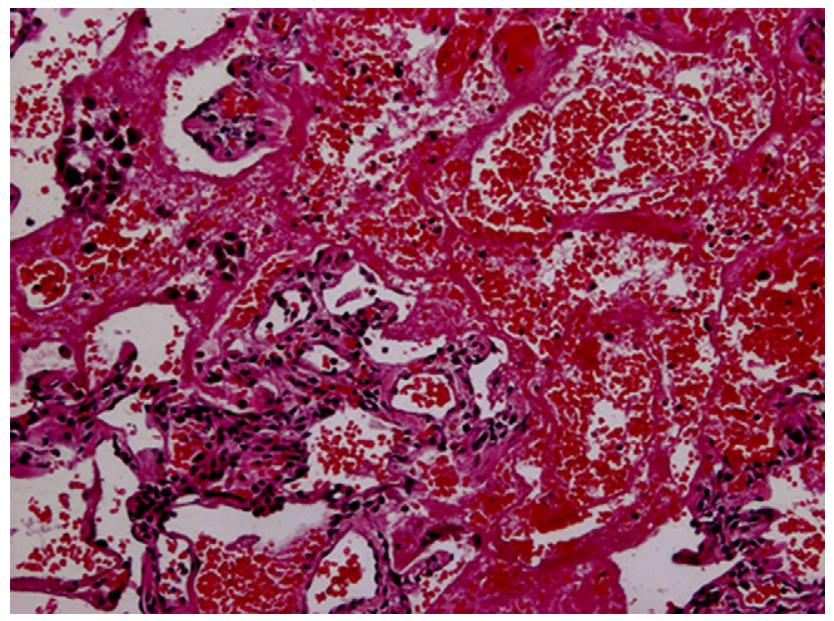

FIGURE E6. Photomicrographs of lung biopsy specimen of patients with tricuspid atresia showing alveolar hemorrhage of a small intra-acinar pulmonary artery (hematoxylin and eosin stain, original magnification $\times 200$ ). 
TABLE E1. Demographics and preoperative characteristics of patients undergoing SCPC and TCPC of the study group $(n=44)$

\begin{tabular}{|c|c|}
\hline Variables & No. \\
\hline Age at operation (mo) & $\begin{array}{l}\text { Mean } \pm \text { SD (range) } \\
83.52 \pm 75.90(17-408),\end{array}$ \\
\hline \multicolumn{2}{|l|}{ Age } \\
\hline$<48$ mo & 34 \\
\hline$>48 \mathrm{mo}$ & 10 \\
\hline Male/female & $32: 12$ \\
\hline Body weight at operation (kg) & $18.23 \pm 11.15(6.5-60)$ \\
\hline Body surface area $\left(\mathrm{m}^{2}\right)$ & $0.74 \pm 0.23(0.32-1.4)$ \\
\hline Previous systemic-PA shunt & 17 \\
\hline Previous PA band & 1 \\
\hline \multicolumn{2}{|l|}{ Preoperative haemoglobin (g/dL) } \\
\hline Mean \pm SD (range) & $16.43 \pm 1.89(11-24)$ \\
\hline \multicolumn{2}{|l|}{ Preoperative hematocrit } \\
\hline$>45 \%$ & 38 \\
\hline$<45 \%$ & 6 \\
\hline \multicolumn{2}{|l|}{$\mathrm{SaO}_{2}$} \\
\hline$<80 \%$ & 37 \\
\hline$>80 \%$ & 7 \\
\hline $\begin{array}{l}\text { Coil embolization of major aortopulmonary } \\
\text { collateral arteries }\end{array}$ & 9 \\
\hline Right aortic arch & 16 \\
\hline Atrial isomerism & 9 \\
\hline \multicolumn{2}{|l|}{ Indexed aortic diameter $\left(\mathrm{mm} / \mathrm{m}^{2}\right)$} \\
\hline Mean \pm SD (range) & $25.8 \pm 9.71(0-78)$ \\
\hline Dilated aortic root & 28 \\
\hline \multicolumn{2}{|l|}{ Aortic regurgitation } \\
\hline Present & 10 \\
\hline Absent & 34 \\
\hline \multicolumn{2}{|l|}{ Anomalous systemic venous drainage } \\
\hline Present & 3 \\
\hline Absent & 41 \\
\hline \multicolumn{2}{|l|}{$\begin{array}{l}\text { Significant left atrioventricular valve } \\
\text { regurgitation }\end{array}$} \\
\hline Nil & 39 \\
\hline Mild & 3 \\
\hline Moderate/severe & 2 \\
\hline \multicolumn{2}{|l|}{ Systemic ventricular ejection fraction } \\
\hline$<50 \%$ & 28 \\
\hline \multicolumn{2}{|l|}{ Systemic ventricular end-diastolic pressure } \\
\hline$>12 \mathrm{~mm} \mathrm{Hg}$ & 14 \\
\hline \multicolumn{2}{|l|}{ PAP (mm Hg) } \\
\hline Mean \pm SD (range) & $14.25 \pm 1.78(12-18)$ \\
\hline \multicolumn{2}{|l|}{ PVR (Wood units/m²) } \\
\hline Mean \pm SD (range) & $1.8 \pm 0.31(1.4-2.6)$ \\
\hline \multicolumn{2}{|l|}{ Reconstruction of LPA, RPA narrowing } \\
\hline Yes & 9 \\
\hline No & 35 \\
\hline \multicolumn{2}{|l|}{ Cardiac morphology } \\
\hline Tricuspid atresia & 29 \\
\hline Nontricuspid atresia & 15 \\
\hline SCPC & 29 \\
\hline TCPC & 15 \\
\hline Lateral tunnel & 13 \\
\hline Extracardiac TCPC & 2 \\
\hline
\end{tabular}

Mean \pm SD (range)

$$
>48 \mathrm{mo}
$$

Body surface area $\left(\mathrm{m}^{2}\right)$

Previous PA band

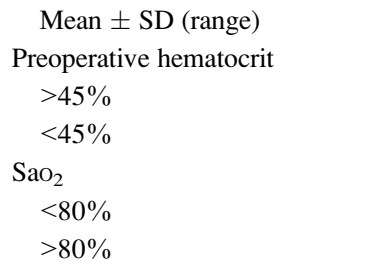

TABLE E1. Continued

\begin{tabular}{lc}
\hline \multicolumn{1}{c}{ Variables } & No. \\
\hline Primary TCPC & 10 \\
Staged palliation (SCPC followed by TCPC) & 5 \\
Postoperative Glenn pressure (patients & \\
$\quad$ undergoing SCPC) & $13.68 \pm 3.21(10-27)$ \\
$\quad$ Mean \pm SD (range) & \\
Postoperative right atrial pressure (patients & \\
$\quad$ undergoing TCPC) & $13.73 \pm 1.83(12-18)$ \\
$\quad$ Mean \pm SD (range) & \\
\hline$S C P C$, Superior cavopulmonary connection; $T C P C$, total cavopulmonary connection; \\
$P A$, pulmonary artery; $S D$, standard deviation; $S a O_{2}$, systemic arterial oxygen satura- \\
tion; $P A P$, pulmonary artery pressure; $P V R$, pulmonary vascular resistance; $L P A$, left \\
pulmonary artery; $R P A$, right pulmonary artery.
\end{tabular}

Age 
TABLE E2. Pairwise comparisons of the indexed area, diameter, and medial and intimal thickness of the intra-PAs of patients undergoing TCPC and SCPC $(n=44)$

\begin{tabular}{|c|c|c|c|}
\hline Variables & Group I (TCPC): mean \pm SD (range) & Group II (SCPC): mean \pm SD (range) & $P$ value \\
\hline $\begin{array}{l}\text { Mean indexed area of the } \\
\text { intra-PAs }\left(\mu \mathrm{m}^{2} / \mathrm{m}^{2}\right)\end{array}$ & $27957.82 \pm 13726.57(7599.55-52044.72)$ & $36125.89 \pm 24493.69(6392.82-99959.62)$ & .45 \\
\hline $\begin{array}{l}\text { Mean indexed diameter of the } \\
\text { intra-PAs }\left(\mu \mathrm{m} / \mathrm{m}^{2}\right)\end{array}$ & $258.59 \pm 92.03(96.23-413.33)$ & $357.44 \pm 165.05(127.28-898.37)$ & $.03^{*}$ \\
\hline $\begin{array}{l}\text { Mean indexed medial thickness } \\
\text { of the intra-PAs }\left(\mu \mathrm{m} / \mathrm{m}^{2}\right)\end{array}$ & $12.36 \pm 5.75(5.55-26.14)$ & $15.83 \pm 7.05(4.11-35.78)$ & .08 \\
\hline $\begin{array}{l}\text { Mean indexed intimal thickness } \\
\text { of the intra-PAs }\left(\mu \mathrm{m} / \mathrm{m}^{2}\right)\end{array}$ & $3.79 \pm 1.54(1.92-7.16)$ & $5.03 \pm 2.42(1.59-11.48)$ & .07 \\
\hline $\begin{array}{l}\text { Mean indexed media/intima ratio } \\
\text { of the intra-PAs }\end{array}$ & $3.56 \pm 1.93(1.83-7.78)$ & $3.56 \pm 1.89(0.85-9.88)$ & .70 \\
\hline Mean indexed density $\left(\mathrm{mm}^{2}\right)$ of the intra-PAs & $5.06 \pm 1.53(3-8)$ & $5.41 \pm 1.43(3-8)$ & .67 \\
\hline
\end{tabular}

$P A$, Pulmonary artery; $T C P C$, total cavopulmonary connection; $S C P C$, superior cavopulmonary connection; $S D$, standard deviation. *Statistically significant.

TABLE E3. Correlations between the histomorphometrically derived parameters and preoperative demographics of patients undergoing TCPC and SCPC $(n=44)$

\begin{tabular}{|c|c|c|c|c|c|c|c|c|c|c|}
\hline \multirow[b]{2}{*}{ Variables } & \multicolumn{2}{|c|}{ Age (mo) } & \multicolumn{2}{|c|}{ Body weight (kg) } & \multicolumn{2}{|c|}{ BSA $\left(\mathbf{m}^{2}\right)$} & \multicolumn{2}{|c|}{ Hematocrit $(\%)$} & \multicolumn{2}{|c|}{$\mathrm{SaO}_{2}(\%)$} \\
\hline & $r$ & $\boldsymbol{P}$ & $r$ & $\boldsymbol{P}$ & $r$ & $\boldsymbol{P}$ & $r$ & $P$ & $r$ & $\boldsymbol{P}$ \\
\hline \multicolumn{11}{|l|}{ Group 1 (TCPC) } \\
\hline Indexed area $\left(\mu \mathrm{m}^{2} / \mathrm{m}^{2}\right)$ & -0.57 & .02 & -0.74 & .001 & -0.53 & .03 & 0.06 & .83 & 0.64 & .01 \\
\hline Indexed diameter $\left(\mu \mathrm{m} / \mathrm{m}^{2}\right)$ & -0.74 & $<.01$ & -0.85 & .0001 & -0.74 & .001 & 0.28 & .30 & 0.43 & .11 \\
\hline $\begin{array}{l}\text { Indexed medial } \\
\text { thickness }\left(\mu \mathrm{m} / \mathrm{m}^{2}\right)\end{array}$ & -0.48 & .06 & -0.48 & .06 & -0.60 & .01 & -0.00 & .99 & 0.24 & .37 \\
\hline $\begin{array}{l}\text { Indexed intimal } \\
\text { thickness }\left(\mu \mathrm{m} / \mathrm{m}^{2}\right)\end{array}$ & -0.05 & .83 & -0.28 & .31 & -0.30 & .26 & 0.17 & .52 & 0.46 & .08 \\
\hline \multicolumn{11}{|l|}{ Group 2 (SCPC) } \\
\hline Indexed area $\left(\mu \mathrm{m}^{2} / \mathrm{m}^{2}\right)$ & -0.58 & $<.01$ & -0.53 & $<.01$ & -0.51 & $<.01$ & -0.11 & .55 & 0.00 & .96 \\
\hline Indexed diameter $\left(\mu \mathrm{m} / \mathrm{m}^{2}\right)$ & -0.72 & $<.01$ & -0.62 & $<.01$ & -0.68 & $<.01$ & -0.20 & .28 & -0.01 & .95 \\
\hline $\begin{array}{l}\text { Indexed medial } \\
\quad \text { thickness }\left(\mu \mathrm{m} / \mathrm{m}^{2}\right)\end{array}$ & -0.50 & $<.01$ & -0.54 & $<.01$ & -0.41 & $<.01$ & -0.14 & .44 & -0.16 & .38 \\
\hline $\begin{array}{l}\text { Indexed intimal } \\
\text { thickness }\left(\mu \mathrm{m} / \mathrm{m}^{2}\right)\end{array}$ & -0.57 & $<.01$ & -0.66 & $<.01$ & -0.71 & $<.01$ & -0.08 & .64 & 0.25 & .18 \\
\hline
\end{tabular}

Statistically significant values are in bold. $T C P C$, Total cavopulmonary connection; $S C P C$, superior cavopulmonary connection; $B S A$, body surface area; $S a O_{2}$, systemic arterial oxygen saturation. 
TABLE E4. Correlations between the histomorphometrically derived parameters and hemodynamic variables of patients undergoing TCPC and $\operatorname{SCPC}(n=44)$

\begin{tabular}{|c|c|c|c|c|c|c|c|c|}
\hline \multirow[b]{3}{*}{ Variables } & \multicolumn{8}{|c|}{ Histomorphometrically derived parameters of the intra-PAs } \\
\hline & \multicolumn{2}{|c|}{ Indexed area } & \multicolumn{2}{|c|}{ Indexed diameter } & \multicolumn{2}{|c|}{ Indexed medial thickness } & \multicolumn{2}{|c|}{ Indexed intimal thickness } \\
\hline & $r$ & $\boldsymbol{P}$ & $r$ & $\boldsymbol{P}$ & $r$ & $\boldsymbol{P}$ & $r$ & $\boldsymbol{P}$ \\
\hline \multicolumn{9}{|l|}{ Group I (TCPC) } \\
\hline Ejection fraction $(\%)$ & -0.25 & .37 & -0.17 & .53 & -0.14 & 61 & -0.23 & .39 \\
\hline End-diastolic pressure ( $\mathrm{mm} \mathrm{Hg}$ ) & 0.43 & .10 & 0.33 & .22 & 0.26 & .37 & -0.21 & .43 \\
\hline Mean PAP $(\mathrm{mm} \mathrm{Hg})$ & 0.31 & .27 & 0.18 & .50 & 0.29 & .29 & -0.27 & .32 \\
\hline PVR (Wood units $/ \mathrm{m}^{2}$ ) & -0.01 & .95 & -0.09 & .74 & 0.40 & .13 & 0.04 & .86 \\
\hline Pulmonary/systemic flow ratio & -0.26 & .34 & -0.11 & .67 & -0.16 & .55 & 0.07 & .79 \\
\hline Nakata index (units $/ \mathrm{m}^{2}$ ) & 0.14 & .59 & 0.19 & .49 & 0.01 & .95 & 0.11 & .71 \\
\hline \multicolumn{9}{|l|}{ Group II (SCPC) } \\
\hline Ejection fraction $(\%)$ & 0.007 & .96 & 0.01 & .95 & -0.01 & .92 & -0.04 & .80 \\
\hline End-diastolic pressure $(\mathrm{mm} \mathrm{Hg})$ & -0.03 & .85 & -0.09 & .61 & 0.04 & .81 & -0.19 & .31 \\
\hline Mean PAP $(\mathrm{mm} \mathrm{Hg})$ & -0.17 & .35 & -0.25 & .18 & -0.01 & .95 & -0.24 & .20 \\
\hline PVR (Woods units/m²) & -0.31 & .10 & -0.03 & .06 & -0.03 & .86 & -0.26 & .15 \\
\hline Pulmonary/systemic flow ratio & -0.35 & .06 & -0.41 & .02 & -0.39 & .03 & -0.34 & .07 \\
\hline Nakata index (units $/ \mathrm{m}^{2}$ ) & -0.76 & .006 & -0.16 & .39 & -0.03 & .85 & 0.03 & .85 \\
\hline
\end{tabular}


TABLE E5. Odds ratio for potential risk factors for poor outcome after SCPC and TCPC of the study group (bivariate analysis) $(\mathrm{n}=44)$

\begin{tabular}{|c|c|c|c|c|}
\hline Variables & No. & No. $(\%)$ & Risk ratio $(95 \%$ CI $)$ & $P$ value \\
\hline \multicolumn{5}{|l|}{ Operation } \\
\hline TCPC & 15 & $4(26)$ & $4.91(0.78-30.79)$ & .08 \\
\hline SCPC & 29 & $3(10)$ & & \\
\hline \multicolumn{5}{|l|}{ Age } \\
\hline$<48$ mo & 34 & $7(20)$ & - & .31 \\
\hline$>48$ mo & 10 & 0 & & \\
\hline \multicolumn{5}{|l|}{ Sex } \\
\hline Male & 32 & $5(15)$ & $2.01(0.21-19.49)$ & 1.0 \\
\hline Female & 12 & $2(16)$ & & \\
\hline \multicolumn{5}{|l|}{ Body weight } \\
\hline$<10 \mathrm{~kg}$ & 19 & $5(26)$ & $0.32(0.05-2.00)$ & .38 \\
\hline$>10 \mathrm{~kg}$ & 25 & $2(8)$ & & \\
\hline \multicolumn{5}{|l|}{ Hematocrit } \\
\hline$>45 \%$ & 38 & $6(16)$ & $0.75(0.07-7.89)$ & 1.0 \\
\hline$<45 \%$ & 6 & $1(16)$ & & \\
\hline \multicolumn{5}{|l|}{$\mathrm{SaO}_{2}$} \\
\hline$<80 \%$ & 37 & $7(18.9)$ & - & .57 \\
\hline$>80 \%$ & 7 & $0(0)$ & & \\
\hline \multicolumn{5}{|l|}{ Indexed aortic diameter $\left(\mathrm{mm} / \mathrm{m}^{2}\right)$} \\
\hline$>24.80$ & 27 & $5(18)$ & $1.31(0.21-8.03)$ & 1.0 \\
\hline$<24.80$ & 17 & $2(11)$ & & \\
\hline \multicolumn{5}{|l|}{ Aortic regurgitation } \\
\hline Present & 18 & $1(5)$ & $0.68(0.11-4.22)$ & 1.0 \\
\hline Absent & 26 & $6(23)$ & & \\
\hline \multicolumn{5}{|l|}{ Right aortic arch } \\
\hline Present & 18 & $2(10)$ & $0.68(0.11-4.22)$ & 1.0 \\
\hline Absent & 26 & $5(19)$ & & \\
\hline \multicolumn{5}{|l|}{ Anomalous systemic venous drainage } \\
\hline Present & 4 & $1(25)$ & $2.33(0.20-27.02)$ & .45 \\
\hline Absent & 40 & $6(15)$ & & \\
\hline \multicolumn{5}{|c|}{ Major aortopulmonary collateral arteries } \\
\hline Present & 10 & $1(10)$ & $0.64(0.06-6.26)$ & 1.0 \\
\hline Absent & 34 & $6(17)$ & & \\
\hline \multicolumn{5}{|l|}{ Atrial isomerism } \\
\hline Present & 8 & 0 & - & .57 \\
\hline Absent & 36 & $7(19)$ & & \\
\hline \multicolumn{5}{|l|}{ Previous systemic-PA shunt } \\
\hline Present & 17 & $3(17.6)$ & $1.71(0.30-9.67)$ & .66 \\
\hline Absent & 27 & $4(14.8)$ & & \\
\hline \multicolumn{5}{|l|}{ Previous PA band } \\
\hline Yes & 2 & $1(50)$ & $7.4(0.39-137.87)$ & .25 \\
\hline No & 42 & $6(14)$ & & \\
\hline \multicolumn{5}{|l|}{ Cardiac morphology } \\
\hline Tricuspid artesia & 13 & $1(7)$ & $7.4(0.9-137.87)$ & .25 \\
\hline Nontricuspid artesia & 31 & $6(19)$ & & \\
\hline \multicolumn{5}{|c|}{ Reconstruction of LPA, RPA narrowing } \\
\hline Yes & 9 & $2(22)$ & $2.21(0.33-14.58)$ & .58 \\
\hline No & 35 & $5(14)$ & & \\
\hline \multicolumn{5}{|c|}{ Significant left atrioventricular valve regurgitation } \\
\hline Nil & 39 & $7(18)$ & - & 1.0 \\
\hline Mild & 3 & 0 & & \\
\hline Moderate/severe & 2 & 0 & & \\
\hline \multicolumn{5}{|l|}{ Systemic ventricular EF } \\
\hline$<50 \%$ & 28 & $5(18)$ & $1.16(0.18-7.21)$ & 1.0 \\
\hline$>50 \%$ & 16 & $2(12.5)$ & & \\
\hline
\end{tabular}


TABLE E5. Continued

\begin{tabular}{|c|c|c|c|c|}
\hline Variables & No. & No. $(\%)$ & Risk ratio $(95 \%$ CI $)$ & $P$ value \\
\hline \multicolumn{5}{|l|}{ SVEDP } \\
\hline$>12 \mathrm{~mm} \mathrm{Hg}$ & 14 & $4(28.5)$ & $5.6(0.88-35.52)$ & .07 \\
\hline$<12 \mathrm{~mm} \mathrm{Hg}$ & 30 & $3(10)$ & & \\
\hline \multicolumn{5}{|l|}{ Mean PAP } \\
\hline$>15 \mathrm{~mm} \mathrm{Hg}$ & 15 & $5(33)$ & $4.90(0.78-30.80)$ & .16 \\
\hline$<15 \mathrm{~mm} \mathrm{Hg}$ & 29 & $2(6)$ & & \\
\hline \multicolumn{5}{|l|}{ PVR } \\
\hline$>2$ Wood units $/ \mathrm{m}^{2}$ & 7 & $4(57)$ & $8.5(1.26-57.19)$ & .04 \\
\hline$<2$ Wood units $/ \mathrm{m}^{2}$ & 37 & $3(8)$ & & \\
\hline \multicolumn{5}{|l|}{ Intra-PA intimal lesions } \\
\hline Present & 8 & $4(50)$ & $6.6(1.03-2.23)$ & .06 \\
\hline Absent & 36 & $3(8.3)$ & & \\
\hline \multicolumn{5}{|l|}{ Intra-PA thrombosis } \\
\hline Present & 4 & $3(75)$ & $9.0(0.98-82.49)$ & .08 \\
\hline Absent & 40 & $4(10)$ & & \\
\hline \multicolumn{5}{|l|}{ Intra-PA smooth muscle extension } \\
\hline Present & 13 & $5(38.4)$ & $6.44(1.00-41.18)$ & .05 \\
\hline Absent & 31 & $2(6.4)$ & & \\
\hline \multicolumn{5}{|c|}{ Intra-PA interstitial fibrosis/chronic inflammatory cells } \\
\hline Present & 29 & $3(10.3)$ & $6.6(1.03-42.23)$ & 1.0 \\
\hline Absent & 15 & $4(26.6)$ & & \\
\hline \multicolumn{5}{|l|}{ Nakata index } \\
\hline$<200$ units $/ \mathrm{m}^{2}$ & 18 & $6(33)$ & $9.61(1.01-91.15)$ & .03 \\
\hline$>200$ units $/ \mathrm{m}^{2}$ & 26 & $1(4)$ & & \\
\hline \multicolumn{5}{|l|}{ Glenn pressure } \\
\hline$>15 \mathrm{~mm} \mathrm{Hg}$ & 7 & $3(42.8)$ & $17.24(2.33-124.18)$ & .005 \\
\hline$<15 \mathrm{~mm} \mathrm{Hg}$ & 37 & $4(10.8)$ & & \\
\hline
\end{tabular}

Statistically significant values are in bold. $T C P C$, Total cavopulmonary connection; $S C P C$, superior cavopulmonary connection; $C I$, confidence interval; $S a O_{2}$, systemic arterial oxygen saturation; $P A$, pulmonary artery; $L P A$, left pulmonary artery; $R P A$, right pulmonary artery; $E F$, ejection fraction; $S V E D P$, systemic ventricular end-diastolic pressure; $P A P$, pulmonary artery pressure; $P V R$, pulmonary vascular resistance; $P A$, pulmonary artery.

TABLE E6. Pairwise comparisons of the indexed area, diameter, medial thickness, intimal thickness, media/intima ratio, and density of the intraPAs of 2 groups of patients with good and poor outcomes

\begin{tabular}{|c|c|c|c|c|c|c|}
\hline \multirow[b]{2}{*}{ Variables } & \multirow[b]{2}{*}{ Group } & \multicolumn{4}{|c|}{ Outcome } & \multirow[b]{2}{*}{$P$ value } \\
\hline & & $\mathbf{N}$ & Good & $\mathbf{N}$ & Poor & \\
\hline \multirow{2}{*}{$\begin{array}{l}\text { Mean indexed } \\
\text { area of the intra-PAs }\left(\mu \mathrm{m}^{2} / \mathrm{m}^{2}\right)\end{array}$} & I & 11 & $27339.85 \pm 11633.82(12307.81-42950.53)$ & 4 & $29657.24 \pm 20564.14(7599.55-52044.72)$ & .69 \\
\hline & II & 26 & $37202.95 \pm 25151.83(6392.92-99959.62)$ & 3 & $26791.34 \pm 18593.29(8887.06-46004.47)$ & .56 \\
\hline \multirow{2}{*}{$\begin{array}{l}\text { Mean indexed } \\
\text { diameter of the intra-PAs }\left(\mu \mathrm{m} / \mathrm{m}^{2}\right)\end{array}$} & I & 11 & $259.11 \pm 74.91(155.84-358.91)$ & 4 & $257.17 \pm 144.28(96.23-413.33)$ & .79 \\
\hline & II & 26 & $366.25 \pm 168.78(127.28-898.37)$ & 3 & $281.12 \pm 124.57(151.28-399.06)$ & .39 \\
\hline \multirow{2}{*}{$\begin{array}{l}\text { Mean indexed } \\
\text { medial thickness of the } \\
\text { intra-PAs }\left(\mu \mathrm{m} / \mathrm{m}^{2}\right)\end{array}$} & I & 11 & $12.07 \pm 4.38(6.56-19.02)$ & 4 & $13.14 \pm 9.44(5.55-26.14)$ & 69 \\
\hline & II & 26 & $15.62 \pm 7.13(4.11-35.78)$ & 3 & $17.64 \pm 7.40(10.57-25.34)$ & .56 \\
\hline \multirow{2}{*}{$\begin{array}{l}\text { Mean indexed } \\
\text { intimal thickness of the } \\
\text { intra-PAs }\left(\mu \mathrm{m} / \mathrm{m}^{2}\right)\end{array}$} & I & 11 & $3.59 \pm 1.73(1.92-7.16)$ & 4 & $3.55 \pm 0.892(2.36-4.38)$ & 6 \\
\hline & II & 26 & $5.23 \pm 2.48(1.59-11.48)$ & 3 & $3.34 \pm 0.60(2.86-4.02)$ & .13 \\
\hline \multirow{2}{*}{$\begin{array}{l}\text { Mean indexed } \\
\text { media/intima ratio } \\
\text { of the intra-PAs }\end{array}$} & I & 11 & $3.45 \pm 1.74(1.83-7.09)$ & 4 & $3.84 \pm 2.66(2.05-3.80)$ & .89 \\
\hline & II & 26 & $3.37 \pm 1.85(0.85-9.88)$ & 3 & $5.20 \pm 1.61(3.35-6.30)$ & .06 \\
\hline \multirow{2}{*}{$\begin{array}{l}\text { Mean indexed } \\
\text { density }\left(\mathrm{mm}^{2}\right) \text { of the intra-PAs }\end{array}$} & I & 11 & $5.09 \pm 1.51(3-8)$ & 4 & $5 \pm 1.82(3-8)$ & .89 \\
\hline & II & 26 & $5.42 \pm 1.39(3-8)$ & 3 & $5.33 \pm 2.08(3-7)$ & .88 \\
\hline
\end{tabular}

Group I, Total cavopulmonary connection; group II, superior cavopulmonary connection; $P A$, pulmonary artery. 
TABLE E7. Pairwise comparisons of the preoperative and postoperative hemodynamic variables of patients undergoing TCPC (group I) and SCPC (group II) with good and poor outcomes

\begin{tabular}{|c|c|c|c|c|c|c|}
\hline \multirow[b]{2}{*}{ Variables } & \multicolumn{3}{|c|}{ Group I } & \multicolumn{3}{|c|}{ Group II } \\
\hline & Good outcome & Poor outcome & $P$ value & Good outcome & Poor outcome & $P$ value \\
\hline $\mathrm{EF}(\%)$ & $50.81 \pm 5.51(47-60)$ & $47.25 \pm 1.5(46-49)$ & .24 & $51.42 \pm 5.98(46-64)$ & $48.66 \pm 1.15(48-50)$ & .91 \\
\hline $\mathrm{EDP}(\mathrm{mm} \mathrm{Hg})$ & $13.27 \pm 1.84(12-18)$ & $14.5 \pm 1(14-16)$ & .08 & $12.96 \pm 3.34(10-20)$ & 18 & .04 \\
\hline Mean PAP (mm Hg) & $14.9 \pm 1.92(12-18)$ & $16.5 \pm 1.73(15-19)$ & .20 & $13.88 \pm 3.87(10-22)$ & $21 \pm 1.73(19-22)$ & .01 \\
\hline PVR (Wood units/m²) & $1.81 \pm .125(1.6-2)$ & $1.9 \pm .34(1.6-2.4)$ & .78 & $1.94 \pm .30(1.4-3)$ & $2.73 \pm .23(2.6-3)$ & .007 \\
\hline Nakata index (units $/ \mathrm{m}^{2}$ ) & $331.36 \pm 63.28(9218-438)$ & $190 \pm 49.65(117-228)$ & .006 & $267.42 \pm 87.56(164-490)$ & $194.66 \pm 17.47(180-214)$ & .15 \\
\hline Qp/Qs & $1.3 \pm 0.46(0.8-2.2)$ & $0.925 \pm 0.2(0.7-1.1)$ & .11 & $1.3 \pm .56(0.4-2.6)$ & $1.33 \pm .6(0.7-1.9)$ & 1.0 \\
\hline Glenn pressure $(\mathrm{mm} \mathrm{Hg})$ & $13.18 \pm 1.4(12-16)$ & $15.5 \pm 2.51(12-18)$ & .09 & $13 \pm 2.63(10-19)$ & $21 \pm 6(15-27)$ & .01 \\
\hline $\mathrm{RAP}(\mathrm{mm} \mathrm{Hg})$ & $13.27 \pm 1.34(12-16)$ & $15.5 \pm 2.51(12-18)$ & .1 & $5.11 \pm 1.27(4-8)$ & $7 \pm 1(6-8)$ & .02 \\
\hline
\end{tabular}

Statistically significant values are in bold. $T C P C$, Total cavopulmonary connection; $S C P C$, superior cavopulmonary connection; $E F$, ejection fraction; $E D P$, end-diastolic pressure; $P A P$, pulmonary artery pressure; $P V R$, pulmonary vascular resistance; $Q p / Q s$, pulmonary/systemic blood flow; $R A P$, right atrial pressure. 


\begin{tabular}{|c|c|c|c|c|c|c|c|c|c|}
\hline Variables & $\begin{array}{c}\text { Intimal lesions } \\
\text { absent }(n=12)\end{array}$ & $\begin{array}{l}\text { Intimal lesions } \\
\text { present }(\mathbf{n}=\mathbf{3})\end{array}$ & $\begin{array}{c}P \\
\text { value }\end{array}$ & $\begin{array}{l}\text { Intra-PA thrombosis } \\
\text { absent }(n=11)\end{array}$ & $\begin{array}{c}\text { Intra-PA thrombosis } \\
\text { present }(n=4)\end{array}$ & $\begin{array}{c}P \\
\text { value }\end{array}$ & $\begin{array}{c}\text { Smooth muscle } \\
\text { extension } \\
\text { absent }(n=10)\end{array}$ & $\begin{array}{l}\text { Smooth muscle } \\
\text { extension } \\
\text { present }(n=5)\end{array}$ & $\begin{array}{c}P \\
\text { value }\end{array}$ \\
\hline $\mathrm{EF}(\%)$ & $50.41 \pm 5.43(46-60)$ & $47.66 \pm 1.52(46-49)$ & .76 & $50.07 \pm 5.34(46-60)$ & $48.5 \pm .7(48-49)$ & .42 & $50.9 \pm 5.87(46-60)$ & $47.8 \pm 1.09(46-49)$ & .89 \\
\hline EDP (mm Hg) & $13.33 \pm 1.77(12-18)$ & $14.66 \pm 1.15(14-16)$ & .11 & $13.53 \pm 1.85(12-18)$ & 14 & .45 & $13.6 \pm 2.06(12-18)$ & $13.6 \pm .89(12-14)$ & .63 \\
\hline $\begin{array}{l}\text { Mean PAP } \\
\quad(\mathrm{mm} \mathrm{Hg})\end{array}$ & $14.91 \pm 1.83(12-18)$ & $17 \pm 1.73(16-19)$ & .1 & $15.23 \pm 2.08(12-19)$ & 16 & .48 & $15.5 \pm 2.12(12-19)$ & $15 \pm 1.73(12-16)$ & .8 \\
\hline $\begin{array}{l}\text { PVR } \\
\qquad \text { (Wood units } / \mathrm{m}^{2} \text { ) }\end{array}$ & $1.8 \pm .134(1.6-2)$ & $2.03 \pm .32(1.8-2.4)$ & .22 & $1.84 \pm .21(1.6-2.4)$ & $1.85 \pm .07(1.8-1.9)$ & .85 & $1.88 \pm .22(1.6-2.4)$ & $1.78 \pm .1(1.6-1.9)$ & .25 \\
\hline $\begin{array}{l}\text { Nakata index } \\
\quad\left(\text { units } / \mathrm{m}^{2}\right)\end{array}$ & $322.75 \pm 67.3(218-438)$ & $177.33 \pm 52.3(117-210)$ & .009 & $313.69 \pm 72.25(205-438)$ & $163.5 \pm 65.76(117-210)$ & .04 & $335.9 \pm 66.29(205-438)$ & $209.2 \pm 57.01(117-273)$ & .01 \\
\hline Qp/Qs & $1.25 \pm .46(.8-2.2)$ & $.96 \pm .23(0.7-1.1)$ & .3 & $1.21 \pm .46(0.7-2.2)$ & 1.1 & 1 & $1.33 \pm .47(0.7-2.2)$ & $.94 \pm .15(0.8-1.1)$ & .1 \\
\hline $\begin{array}{l}\text { Glenn pressure } \\
\quad(\mathrm{mm} \mathrm{Hg})\end{array}$ & $13.58 \pm 1.92(12-18)$ & $14.66 \pm 2.3(12-16)$ & .4 & $13.76 \pm 1.96(12-18)$ & $14 \pm 2.82(12-16)$ & .92 & $13.6 \pm 1.64(12-16)$ & $14.2 \pm 2.68(12-18)$ & .75 \\
\hline RAP $(\mathrm{mm} \mathrm{Hg})$ & $13.66 \pm 1.87(12-18)$ & $14.66 \pm 2.3(12-16)$ & .45 & $13.84 \pm 1.9(12-18)$ & $14 \pm 2.82(12-16)$ & 1 & $13.7 \pm 1.56(12-16)$ & $14.2 \pm 2.68(12-18)$ & .89 \\
\hline
\end{tabular}

Statistically significant values are in bold. $P A$, Pulmonary artery; $T C P C$, total cavopulmonary connection; $E F$, ejection fraction; $E D P$, end-diastolic pressure; $P A P$, pulmonary artery pressure; $P V R$, pulmonary vascular resistance;

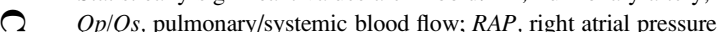

TABLE E9. Pairwise comparisons of the pre and postoperative hemodynamic variables with the lung biopsy findings of the PAs of patients undergoing SCPC

\begin{tabular}{|c|c|c|c|c|c|c|c|c|c|}
\hline Variables & $\begin{array}{c}\text { No intimal } \\
\text { change }(n=24)\end{array}$ & $\begin{array}{c}\text { Intimal change } \\
(\mathbf{n}=\mathbf{5})\end{array}$ & $P$ value & $\begin{array}{l}\text { No PA thrombosis } \\
\quad(n=28)\end{array}$ & $\begin{array}{l}\text { PA thrombosis } \\
\text { present }(n=1)\end{array}$ & $P$ value & $\begin{array}{c}\text { Smooth muscle } \\
\text { extension absent }(n=21)\end{array}$ & $\begin{array}{c}\text { Smooth muscle extension } \\
\text { present }(\mathrm{n}=8)\end{array}$ & $P$ value \\
\hline$F(\%)$ & $51.83 \pm 6.08(46-64)$ & $47.8 \pm .44(47-48)$ & .37 & $51.37 \pm 5.87(46-64)$ & 48 & .79 & $50.76 \pm 6.09(46-64)$ & $52.12 \pm 4.85(47-60)$ & .22 \\
\hline $\mathrm{DP}(\mathrm{mm} \mathrm{Hg})$ & $13.62 \pm 3.65(10-20)$ & $12.8 \pm 3.03(10-18)$ & .97 & $13.37 \pm 3.53(10-20)$ & $15 \pm 4.24(12-18)$ & .37 & $13.04 \pm 3.33(10-20)$ & $14.62 \pm 3.96(10-19)$ & .34 \\
\hline lean PAP (mm Hg) & $15.08 \pm 4.57(10-22)$ & $12.4 \pm 1.14(11-14)$ & .48 & $14.7 \pm 4.44(10-22)$ & $13.5 \pm .7(13-14)$ & .69 & $14.09 \pm 4.07(10-22)$ & $16 \pm 4.84(10-22)$ & .32 \\
\hline VR (Wood units/m²) & $2.07 \pm .39(1.4-3)$ & $1.78 \pm .14(1.6-2)$ & .03 & $2.08 \pm .38(1.4-3)$ & $1.75 \pm .07(1.7-1.8)$ & .09 & $2.01 \pm .4(1.4-3)$ & $2.05 \pm .33(1.6-2.6)$ & .58 \\
\hline Jakata index (units/m²) & $261.95 \pm 91.81(164-490)$ & $250 \pm 54.84(180-312)$ & .66 & $264.85 \pm 86.95(164-490)$ & $193 \pm 18.38(180-206)$ & .21 & $252.42 \pm 84.93(164-490)$ & $279.5 \pm 91.01(180-450)$ & .31 \\
\hline $\mathrm{p} / \mathrm{Qs}$ & $1.27 \pm .57(.4-2.6)$ & $1.44 \pm 0.45(1-2)$ & .46 & $1.29 \pm 0.55(.4-2.6)$ & $1.5 \pm 0.7(1-2)$ & .51 & $1.29 \pm 0.49(.4-2.1)$ & $1.35 \pm 0.73(.5-2.6)$ & .94 \\
\hline Flenn pressure $(\mathrm{mm} \mathrm{Hg})$ & $13.83 \pm 4.08(10-27)$ & $13.8 \pm 2.94(12-19)$ & .9 & $13.88 \pm 4(10-27)$ & 13 & 1 & $13.52 \pm 3.15(10-21)$ & $14.6 \pm 5.5(10-27)$ & .94 \\
\hline $\mathrm{AP}(\mathrm{mm} \mathrm{Hg})$ & $5.29 \pm 1.48(4-8)$ & $5.4 \pm .54(5-6)$ & .56 & $5.29 \pm 1.4(4-8)$ & $5.5 \pm .7(5-6)$ & .65 & $5.09 \pm 1.09(4-7)$ & $5.87 \pm 1.88$ & .34 \\
\hline
\end{tabular}

$P A$, Pulmonary artery; $S C P C$, superior cavopulmonary connection; $E F$, ejection fraction; $E D P$, end-diastolic pressure; $P A P$, pulmonary artery pressure; $P V R$, pulmonary vascular resistance; $Q p / Q s$, pulmonary/systemic blood flow; $R A P$, right atrial pressure. 